\title{
Organization and patterns of interactions in a subtidal sand community on an exposed coast
}

\author{
J. G. Morin, J. E. Kastendiek* , A. Harrington \& N. Davis** \\ Department of Biology, University of California, Los Angeles, California 90024, USA
}

\begin{abstract}
Temporal and spatial patterns of distribution of the macroscopic epifauna of an exposed nearshore sand habitat in southern California were monitored from early 1970 to early 1975. This community is dominated by relatively large, long-lived suspension feeders that experience low successful recruitment and low predation rates. Of the 3 distinct zones, the shallow shoreward zone (water depths 2.6 to $6.4 \mathrm{~m}$ ) is characterized by a harsh physical environment of unstable, shifting sands and strong wave surge, few species and individuals (mainly the clam Tivela stultorum and the sea pansy Renilla kollikerl), and a relatively low biomass. In the middle zone (water depths 6.4 to $9.1 \mathrm{~m}$ ) there is moderate surge but relatively little sand fluctuation, and a high density (up to $1200 \mathrm{~m}^{-2}$ ) of sand dollars Dendraster excentricus. The sand dollars form a bed that has distinct seaward and shoreward edges; densities increase toward the seaward margin. The shoreward edge is relatively stable and is located where major sand fluctuations increase significantly toward the shore. The outer edge of the bed expands seaward in the fall and contracts shoreward in the spring. This middle zone shows the greatest numbers of total individuals and total biomass of the 3 zones. The seaward zone (water depths of 9.1 to $13.1 \mathrm{~m}$ ) is physically the most stable. The surge velocity is generally low and sand movement is negligible. The zone is dominated by $R$. kollikeri, the sea pen Stylatula elongata, the tube worm Diopatra ornata and the sand star Astropecten verrilli, but shows the greatest species diversity (mainly as motile predators), few individuals, and a relatively low biomass. The shoreward distribution of many of these various motile forms appears to be physically limited during the summer by wave surge and biologically limited during the winter by competition with migrating sand dollars. Fishes and crustaceans, which occur over all zones, are primarily evident at night. However, unlike animals from hard substrate marine communities, they have no ecological equivalents within the community by day. Long-term fluctuations and periodic successful recruitment in some of the species have been detected.
\end{abstract}

\section{INTRODUCTION}

Most soft-bottom organisms, because they dwell in or on a somewhat fluid substrate, rarely are truly sessile. Most possess various means of at least limited locomotion so that they can adjust to the vagaries of the shifting sands. On the open coast this limited mobility produces some rather unexpected long term interactions between members of the various zones and leads to a dynamic interplay between the physical environment and the component species.

Distinct patterns of distribution and abundances of organisms can be found in any marine habitat. The

\footnotetext{
- Present address: Marine Review Committee, Inc., 531 Encinitas Blvd., Encinitas, California 92024, USA

- Present address: Chambers Consultants and Planners, 10557 Beach Boulevard, Stanton, California 90680, USA
}

agents responsible for recurrent assemblages are often complex combinations of biological and physical factors. The effects of these factors on soft-substrate communities have been studied in the quiet waters of bays, harbors, estuaries and lagoons; in the intertidal; and primarily with the infauna and not the epifauna (e.g. Woodin 1974, 1978, 1981, Virnstein 1977, 1979, Peterson 1977, Peterson \& Andre 1980, Wiltse 1980, Smith 1981). These and other studies have variously demonstrated the importance of disturbance, refuges, recruitment, food resources, predation, and competition in influencing the structure of soft-bottom communities. However, the preponderance of soft-substrate communities occur on vast subtidal surge-swept sand bottoms throughout the majority of the world's coastlines. For instance, most of the nearshore subtidal coastline off southern California consists of gradually sloping bottoms of soft sediments. Organisms in these regions 
are confronted by a physically rigorous and structurally unstable, but relatively predictable and homogeneous habitat. The benthic environment changes markedly from one of nearly constant sweeping surge and continually shifting sands nearshore to one with gentle surge and relatively stable sands at distances well beyond the surf zone. These habitats, because of their physically stressful nature and relatively depauperate appearance, have been little studied. However, Fager (1968), Merrill \& Hobson (1970), Davis \& VanBlaricom (1978), Oliver et al. (1980), Kastendiek (1982) and VanBlaricom (1982) have shown that distinct community assemblages exist in such subtidal high-energy beaches off the west coast of the United States. Merrill \& Hobson (1970) demonstrated that the principal epifaunal member of most of these shallow west coast exposed sand habitats is the sand dollar Dendraster excentricus, which occurs in immense numbers in distinct beds. Because of their ubiquity, relative structural simplicity and homogeneity, these subtidal sand beaches with large $D$. excentricus populations represent attractive and ecologically important regions for examining questions dealing with the effects of physical and biological factors upon marine populations.

The present study was undertaken (1) to quantitatively delineate the organization of an epifaunal community occupying an exposed subtidal sand bottom habitat off California and (2) to examine the complex interactions between its various constituents and the environment over time spans of days, seasons and years. We suggest that there are some unique roles that refuges, physical and biological disturbance, predation, competition, foraging strategies, and successful recruitment play in determining the structure of this surge-exposed subtidal sand community.

\section{MATERIALS AND METHODS}

Zuma Beach $\left(118^{\circ} 50^{\prime} \mathrm{W}, 34^{\circ} 01^{\prime} \mathrm{N}\right)$ is an exposed, southwest facing sand beach (Fig. 1) $35 \mathrm{~km}$ northwest of Los Angeles, California. The strand is $6 \mathrm{~km}$ long and is bounded at its 2 ends by rocky headlands. A submarine canyon, Dume Canyon, runs southeastward from the Point Dume headland. Two freshwater streams, which flow intermittently during the rainy season each year (November through March), terminate along the beach. The Los Angeles County Lifeguards record beach and weather conditions (including air and sea temperatures, wind speed and direction, sky and sea surface conditions, surf height and direction, beach contour [eroding, depositing or holding], and long-shore current direction) 3 times each day (dawn, noon and dusk) at Zuma Beach. They generously allowed us to use their records.

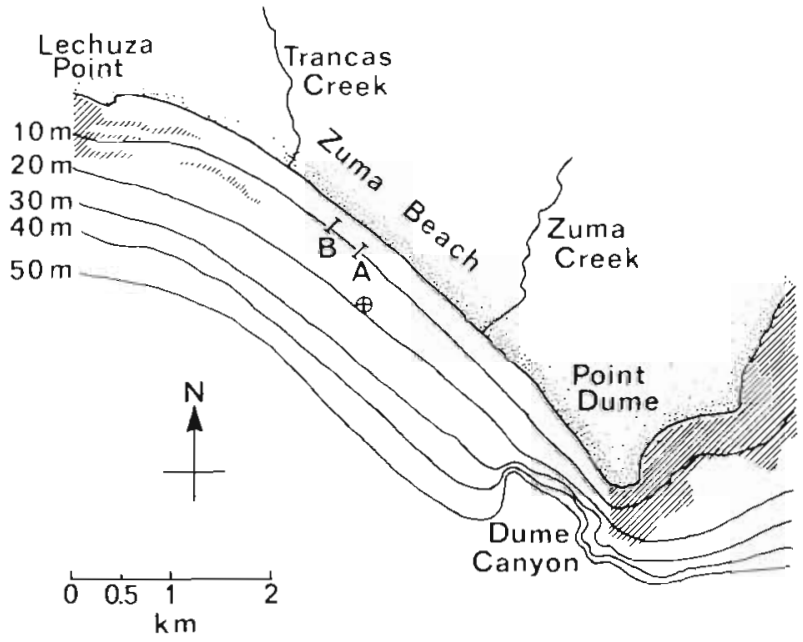

Fig. 1. Locations of the subtidal study sites off Zuma Beach Los Angeles County, California. A: Transect $A_{i}$ B: Transect $B_{i}$ $\oplus$ marks the position of $118^{\circ} 50^{\prime} \mathrm{W}, 34^{\circ} 01^{\prime} \mathrm{N}$; hatched areas indicate subtidal rocky outcrops; depth contours in meters

Distributional data were collected from March 1970 to January 1975 by divers using scuba. Initially a single $180 \mathrm{~m}$ transect (A in Fig. 1) was positioned subtidally near the midpoint of the beach and perpendicular to its face. The transect was permanently marked by stakes at 4.8,10.5 (near the midpoint) and $13.1 \mathrm{~m}$ depth (MLLW). A polypropylene line, marked in meter intervals, was attached to the stakes during the counting periods. In order to minimize any effects of the survey upon the community, only the stakes remained on the bottom between monitorings. The nearshore stake (at $4.8 \mathrm{~m}$ depth) of this 'A' transect was approximately $130 \mathrm{~m}$ from the mean tide level on the beach (the distance ranged from $150 \mathrm{~m}$ in the winter to about $110 \mathrm{~m}$ in the summer). The distance between the inner end of the transect and the surfline averaged about $80 \mathrm{~m}$ but varied with changes in season, tide and surf conditions.

In order to compare characteristics along the beach, a second similar transect (B in Fig. 1) was positioned $0.4 \mathrm{~km}$ west of the original transect in October 1971. The only difference was that Transect ' $B$ ' was placed with its nearshore stake $30 \mathrm{~m}$ closer to shore (at a depth of about $2.6 \mathrm{~m}$ ) than in Transect ' $\mathrm{A}$ ' To avoid any possible effect of freshwater outflow, each transect was at least $0.7 \mathrm{~km}$ from a stream outlet. There are no known subtidal rock outcrops within $0.7 \mathrm{~km}$ of either transect. Analysis of data from the 2 transects showed no significant topographic or faunistic difference between them, so data collected from both were usually combined and normalized, thus resulting in a total transect length of $210 \mathrm{~m}$.

Species distributions and numbers of macroscopic epifauna ( $>$ about $5 \mathrm{~mm}$ ) and partially visible infauna 
(such as clam siphons of Tivela stultorum, anemones and some annelids) were determined by counting individuals within a $1 \mathrm{~m}$ wide path along each $5 \mathrm{~m}$ interval of the transect. Because of their abundance, densities of the sand dollar Dendraster excentricus, either on or buried in the sand, were obtained from counts of individuals within a $0.1 \mathrm{~m}^{2}$ ring. The ring was tossed blindly at 5 or $10 \mathrm{~m}$ intervals along the transect; usually 3 counts were made at each of these intervals. Using a $1 \mathrm{~mm}$ mesh sieve, the top few $\mathrm{cm}$ of sand within each ring was sieved periodically in order to reveal the presence of juvenile sand dollars and postlarvae of other species. In an effort to collect data on the less abundant and more errant forms, particularly the crabs and fishes, we occasionally ran transects of $10 \mathrm{~m}$ width. Seven divers collected data at various times during the study; all transects were done by the authors and occasionally 2 transects were run side by side to check accuracy and consistency. Raking of the transects on several occasions revealed almost no buried epifaunal organisms. Complete transect runs were distributed evenly throughout the year. Transect runs averaged slightly less than 2 per month in 1971 , 3 per month in 1972, and 1 per month in 1973 and 1974. A total of 65 complete transects and 28 partial transects (i.e. the shoreward $100 \mathrm{~m}$ including the sand dollar bed) were carried out during the study and these, along with other special censusing and observational dives, represent 208 dives involving about 554 person hours of underwater working time in the 2 transect areas. A total of 7 transects and 6 more observational dives were made at night in order to determine diel changes.

\section{RESULTS}

\section{Physical characteristics}

The ocean floor in the study area is sand and varies in slope from $7 \%$ in the nearshore to $3 \%$ in the deepest region (Fig. 2). The depth of the transects (Fig. 2) ranges from $2.6 \mathrm{~m}$ to $13.1 \mathrm{~m}$ (MLLW). The sand is highly sorted (sorting coefficient $=0.45$ ) along the entire length of the transect. Mean grain size increases as water depth decreases along the transect, and along Transect 'A' varies from $0.24 \mathrm{~mm}$ (at $4.8 \mathrm{~m}$ depth) to $0.19 \mathrm{~mm}$ (at $13.1 \mathrm{~m}$ depth) in winter and from $0.22 \mathrm{~mm}$ (at $4.8 \mathrm{~m}$ depth) to $0.19 \mathrm{~mm}$ (at $13.1 \mathrm{~m}$ depth) in summer

The physical factor probably most influential to the biota in the shallow subtidal sand community is the ocean swell and its accompanying wave surge. The effect of the surge decreases as the water depth increases. On days of small surf ( 0.3 to $0.6 \mathrm{~m}$ in height) surge and sand movements are noticeable only in waters shallower than $6.5 \mathrm{~m}$ depth (i.e. throughout the nearshore $55 \mathrm{~m}$ of the combined transect; called the shoreward zone). Larger surf ( 1.5 to $2 \mathrm{~m}$ ) develops strong water currents that are able to move a layer of sand to and fro along the bottom along the entire transect. This sand movement buffets the fauna and also either buries most of the animals under shifting sands or causes them to actively burrow. On more typical days the surf averages 0.6 to $1 \mathrm{~m}$, which, at a depth of $6.5 \mathrm{~m}$ (the $55 \mathrm{~m}$ point on the transect), results in maximum surge velocities of about $1 \mathrm{~m} \mathrm{~s}^{-1}$.

The nearshore depth profile changes with the seasons. These alternations are caused by the ocean swell that varies throughout the year in size, period and direction. The winter surf (January through March) with a mean height of about $1 \mathrm{~m}$ (range from $0.2 \mathrm{~m}$ to $3 \mathrm{~m})$, strikes the beach from the west and southwest (Emery 1960, Bascom 1964, Meyer 1972, Los Angeles County Lifeguard data for Zuma Beach). The North Pacific storm swells with their large, short-period waves attack the berm of the beach and the eroded sand is deposited as sand bars offshore. The effect of this sand transport is apparent throughout the shoreward $55 \mathrm{~m}$ of the transect (Fig. 2); beyond this region
Fig. 2. Sea water depth (in meters at MLLW) and the maximum recorded change in vertical sand levels (measured in $\mathrm{cm}$ on 6 permanent stakes) at various positions along the combined transect (in meters). Biological zones (1-3) also indicated. (O) Water depth; $(\bullet)$ measurements from Transect $\mathrm{B}_{i}(\mathbf{C})$ measurements from Transect $\mathrm{A}$

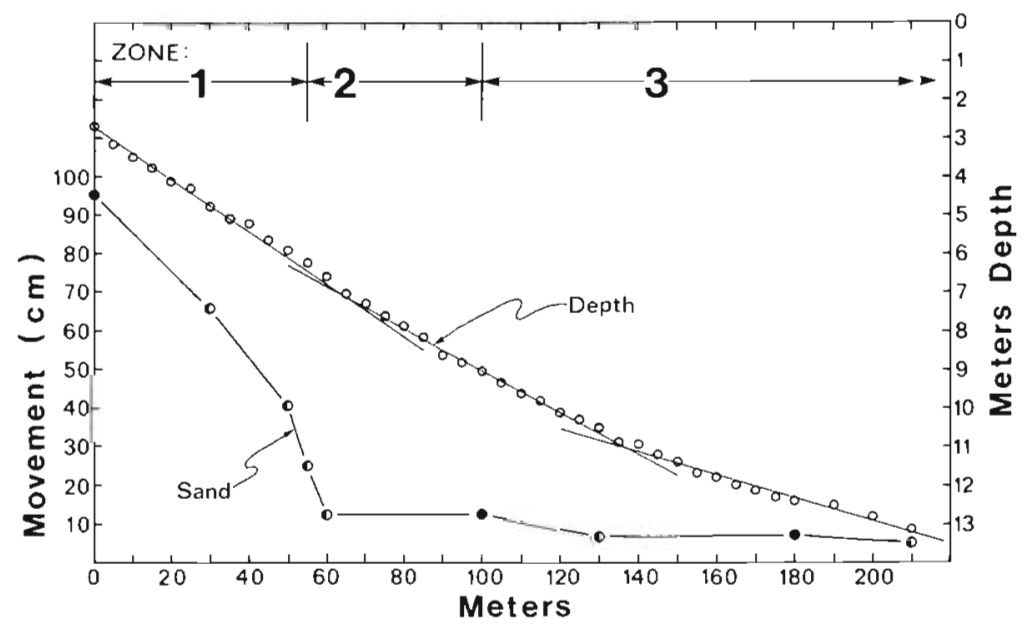


there is little change in the bottom contour on either a short or long term basis.

The surf in summer (July through September) is generally from the south, of smaller height (mean about $0.6 \mathrm{~m}$ ), and of a longer period. The net effect of this summer swell is the deposition of sand along the beach face, and concomitant breakdown of the offshore sand bars; the bar is absent throughout the summer (Emery 1960, Bascom 1964, Meyer 1972, Las Angeles

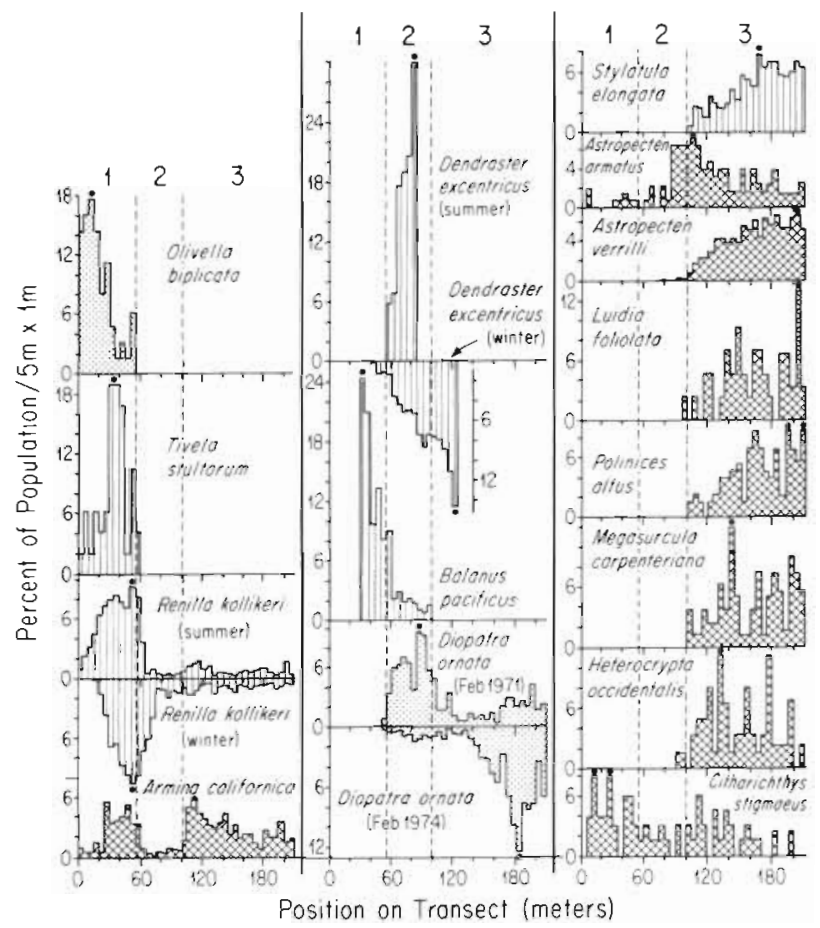

Fig. 3. Distribution along the combined transect of the most common animals at Zuma Beach. Zones 1, 2 and 3 are identified. Distribution is given as $\%$ of total per $5 \mathrm{~m} \times 1 \mathrm{~m}$ increment. Stippled: scavenger-deposit feeding organisms; vertical hatching: suspension feeding organisms; cross hatching: carnivorous organisms; (.) position of average peak density. These densities are given as follows (in no. $100 \mathrm{~m}^{-2}$ ): Olivella biplicata $=55$, Tivela stultorum $=45$, Renilla kollikeri summer $=580, R$. kollikeri winter $=465$, Armina californica $=8.2$, Dendraster excentricus summer $=93,000, D$. excentricus winter $=39,000$, Balanus pacificus $=0.23(100$ sand dollars) ${ }^{-1}$, Diopatra ornata $19 \overrightarrow{7} 1=680$, D. ornata 1974 $=1560$, Stylatula elongata $=60$. Astropecten armatus $=3.3$, A. verrilli $=29$, Luidia foliolata $=1.2$, Polinices altus $=3.1$, Megasurcula carpenteriana $=2.2$, Heterocrypta occidentalis $=2.1$. Citharichthys stigmaeus $=2.4$. Other common organisms (seen on more than 20 of the dives), not shown because of their low densities and even distribution throughout the transects, showed average transect densities (in no. $100 \mathrm{~m}^{-2}$ ) of: Cancer gracilis $=1.8$, Randallia ornata $=0.23$. Loxorhynchus grandis $=0.19$, Isocheles pilosus $=0.19$, Hypsopsetta guttulata $=0.14$, Pleuronichthys coenosus $=0.27$, Paralich thys californica $=0.072$. Average peak densities of animals associated with seaward edge of the sand dollar bed (see Fig. 8) were: Pisaster brevispinus $=0.10$ ind $100 \mathrm{~m}^{-2}$, Pisaster giganteus $=0.085$ ind $100 \mathrm{~m}^{-2}$, Balcis rutila $=28.2$ ind $(100$ sand dollars) ${ }^{-1}$
County Lifeguard data). Although the mean height of the surf during the summer is less than that of winter, the largest waves (up to $5 \mathrm{~m}$ ) striking the beach throughout the year usually occur in August and September. These waves are a result of storm activity in the southern hemisphere and Pacific hurricanes off Mexico and Central America.

Other phenomena linked to prevailing surf conditions are longshore and rip currents. The more westerly winter swell generally but not always results in a southeasterly longshore current and, conversely, the more southerly summer swell generally results in a northwesterly longshore current. Both longshore and rip currents can be quite strong (over $1 \mathrm{~m} \mathrm{~s}^{-1}$ ) and result in complex patterns of water movement and concomitant sand transport, both of which may exert a significant effect on the bottom fauna, particularly in the shoreward $55 \mathrm{~m}$ of the transect.

Sea temperatures range from a minimum of about $10^{\circ} \mathrm{C}$ in March and April to a maximum of about $21^{\circ} \mathrm{C}$ in August. Temperature stratifications occur occasionally, but due to turbulent mixing the inshore surface temperature usually does not differ markedly from bottom temperatures within the transect area.

Because of lack of available solid substrate, there are few attached macroalgae except for small amounts growing on the tubes of the annelid Diopatra ornata and dead clam (Tivela stultorum) shells. However, large amounts of drift algae are often moved into the area along the bottom by longshore currents. The sources of the drift algae are the rocky headlands and kelp beds to the east and west of Zuma Beach (Fig. 1).

\section{Spatial distribution of fauna}

Along the combined transect the distributions of most of the common epifaunal animals can be segregated into 3 distinct zones (Fig. 3). The zonal distribution, relative occurrence, number observed per dive, and position relative to the substrate of all organisms encountered during the study will be presented elsewhere (Morin et al. unpubl.).

\section{Shoreward zone (Zone 1)}

In water depth this zone varies from about $2.6 \mathrm{~m}$ to about $6.4 \mathrm{~m}$ (MLLW), which is 0 to $55 \mathrm{~m}$ horizontally along the combined transect (see Fig. 3). Physically the zone is characterized by a fairly steep slope of about $7 \%$ and substantial temporal changes in sand levels at a given depth (Fig. 2). Average increases or decreases of sand depths of 1.6 to $1.7 \mathrm{~cm} \mathrm{~d}^{-1}$ for periods of up to 1 mo have been measured on our inshore $(0 \mathrm{~m})$ stake.

Zone 1 is numerically dominated (Fig. 3) by the 

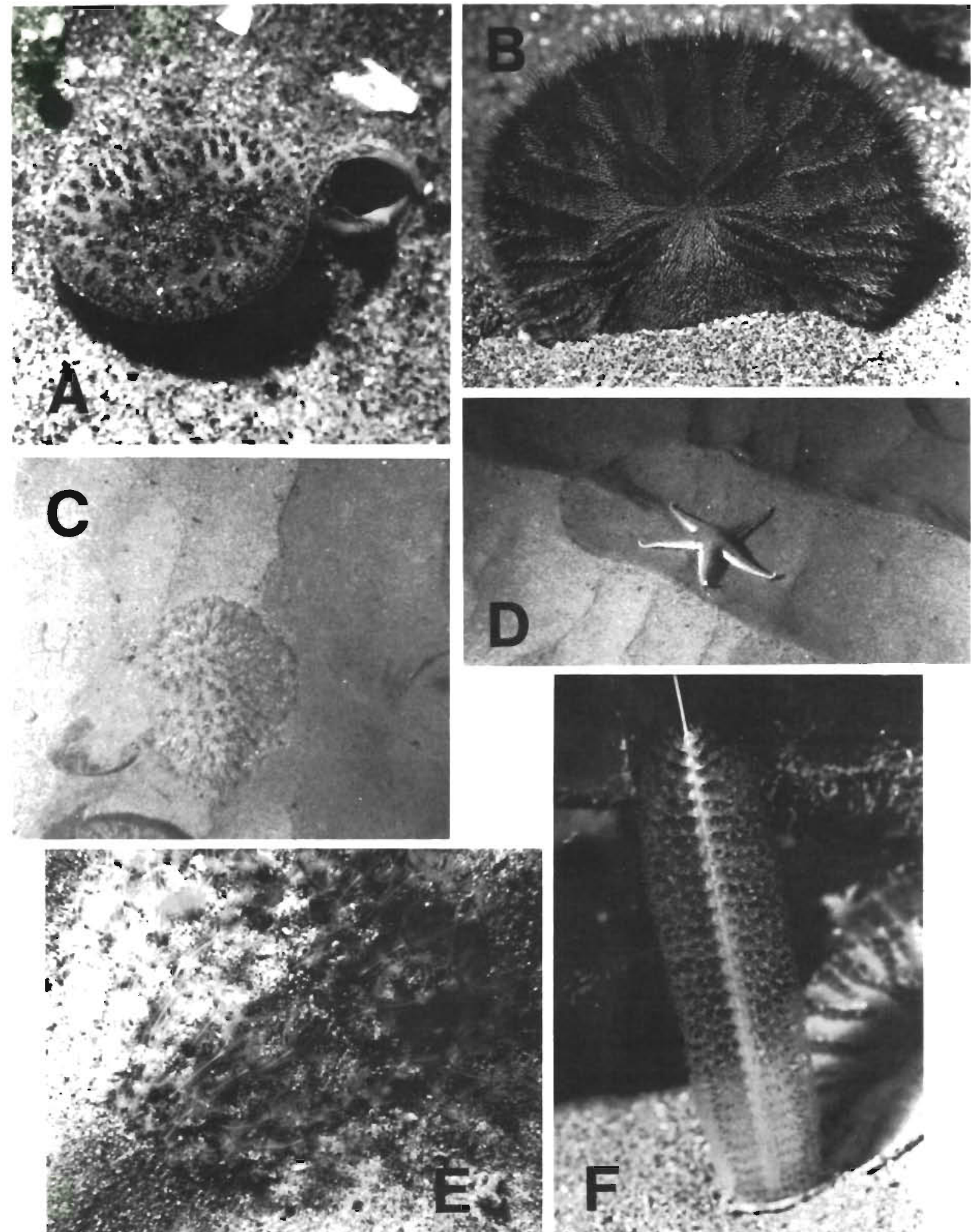

Fig. 4. Dominant organisms of the shallow subtidal sand community at Zuma Beach: (A) exposed siphons of the Pismo clam Tivela stultorum (the incurrent siphon, ca $2 \mathrm{~cm}$ diameter, is to the left); (B) the aboral side of the sand dollar Dendraster excentricus in its inclined position (ca $7.5 \mathrm{~cm})$; $(\mathrm{C})$ the sea pansy Renilla kollikeri $(\mathrm{ca} 8 \mathrm{~cm})$ with some sand dollars (lower left) near the seaward edge; (D) the sand star Astropecten verrilli, ca $9 \mathrm{~cm}$; (E) close-up of a ca $5 \mathrm{~cm}$ R. kollikeri in Zone 1 ; (F) the sea pen Stylatula elongata, ca $10 \mathrm{~cm}$. A. verrilli is a carnivore, all the others are primarily suspension feeders 
Pismo clam Tivela stultorum and the pennatulacean Renilla kollikeri (Fig. 4). The gastropod Olivella biplicata and the anomuran crab Blepharipoda occidentalis are the shoreward-most members of this zone. During periods of small surf the nudibranch Armina californica, which shows a bimodal distribution with the shoreward peak occurring in Zone 1, and sometimes the sand star Astropecten armatus will be found in Zone 1 (Fig. 3, see also Kastendiek 1982).

Sand dollar or middle zone (Zone 2)

The bottom in this zone has a slope of about $6 \%$ and there are relatively small temporal changes in sand level (Fig. 2). The depth of water ranges from about $6.4 \mathrm{~m}$ to about $9.1 \mathrm{~m}$ (MLLW), which is 55 to $100 \mathrm{~m}$ along the combined transect. The sand dollar Dendraster excentricus (Fig. 4 \& 5), numerically dominates Zone 2. The sand dollar population (Fig. 5) is distinctly aggregated into a large bed (Fig. 3) whose mean density lies between 400 and $500 \mathrm{~m}^{-2}$. These sand dollars typically align their flattened axes perpendicular to the substrate and parallel to the wave surge (the inclined position); the anus is positioned uppermost in the water column. Depending on the season, the bed varies between 25 and $100 \mathrm{~m}$ in its total width (Fig. 6 \& 7 , see below). Both the shoreward and seaward edges of the sand dollar bed are conspicuous. The shoreward limit of the bed is located at the boundary of Zones 1 and 2 and is characterized by an abrupt increase in density from a sparse 10 to $20 \mathrm{~m}^{-2}$ to about $150 \mathrm{~m}^{-2}$ over a distance of $5 \mathrm{~m}$ (Fig. $3 \& 7$ ). This edge remains in the same approximate location on the bottom throughout the year (Fig. 6), although periods of heavy surf can physically displace large numbers of sand dollars and obscure the edge. This surf-caused, diffuse distribution is temporary and, depending on the prevailing surf conditions, the bed margin is reestablished within a few days. Seaward of the inner edge sand dollar densities rise gradually up to the seaward (outer) edge (Fig. $3 \& 7$ ). The outer edge lies in 7.5 to $11.5 \mathrm{~m}$ of water (Fig. 6) and is much more distinct than the inner edge (Fig. $5 \& 7$ ). The highest densities of sand dollars are usually found along the outside edge. Densities change from this maximum to nil within a horizontal seaward distance of less than $1 \mathrm{~m}$ (Fig. $5 \& 7$ ).

Certain organisms are usually associated with the sand dollars. Heptacarpus sp., an inconspicuous small caridean shrimp, is frequently found between the sand dollars throughout the bed. The sand barnacle Balanus pacificus fouls living sand dollars. This barnacle also can be found wherever there is solid substrate available in the sand (e.g. small rocks, dead clam shells, crab carapaces), but they predominate on sand dollars (see also Hurley 1973). About $2 \%$ of the sand dollars have barnacles growing on them (Fig. 3). Usually the barnacles are positioned aborally, opposite the sand dollar's anus. The number of fouled sand dollars is highest near shore in Zone 1 where sand dollar densities are low (Fig.3). Balcis rutila, a small ectoparasitic eulimid gastropod, is commonly found attached to Dendraster excentricus. Balcis rutila is also found on the echinoderms Pisaster brevispinus, Astropecten armatus and Molpadia arenicola. The peak abundance of $B$. rutila is associated with stray sand dollars found seaward of the outer edge of the bed and drops progressively shoreward into the bed (Fig. 3 legend \& Fig. 8). A. armatus is most abundant at the outside edge of the bed (Fig. $3 \& 8$ ). P. brevispinus and $P$. giganteus, which prey largely on sand dollars in this habitat (MacGinitie \& MacGinitie 1949), are also most commonly found along the outside edge of the sand dollar bed (Fig. 3 legend \& Fig. 8). The onuphid polychaete Diopatra ornata shows a bimodal population distribution with the nearshore peak within the sand dollar bed (Fig. 3).

\section{Seaward zone (Zone 3)}

This zone (Fig. 2) has a slope of about $3 \frac{1}{2} \%$ and the water depth ranges from about $9.1 \mathrm{~m}$ to $13.1 \mathrm{~m} \mathrm{(100} \mathrm{to}$ $210 \mathrm{~m}$ along the combined transect). Of the 3 zones, this is the least affected by wave surge and sand movement (Fig. 2). A thin diatom layer often covers most of this region, further indicating negligible substrate movement. This seaward zone is numerically dominated (Fig. $3 \& 4$ ) by the sedentary suspension feeding pennatulacean Stylatula elongata and to a lesser extent by Renilla kollikeri, the motile predator Astropecten verrilli, and the sessile omnivorescavenger Diopatra ornata. R. kollikeri (Fig. 4), shows a shallow (Zone 1) peak, a low point of density within the area of high sand dollar density (Zone 2), and then a minor second peak in Zone 3 and a consistently low density to (and beyond) the outer end of the transect (Fig. 3). The Zone 3 R. kollikeri are larger than most of those in Zone 1 (see Kastendiek 1976, 1982). The nudibranch Armina californica, which feeds preferentially on $R$. kollikeri (Ricketts et al. 1968, Kastendiek 1976, 1982) has its highest density within Zone 3, particularly where the prey densities are highest. The sedentary annelid $D$. ornata showed some distinctive changes in abundances during the study period (Fig, 3).

The majority of the organisms associated with this zone are consistently found seaward of the $9.1 \mathrm{~m}$ depth boundary (100 $\mathrm{m}$ on the transect) and most increase up to a peak density in the range of $10.6 \mathrm{~m}$ to $13.1 \mathrm{~m}$ depth (130 to $210 \mathrm{~m}$ along the transect) (Fig. 3). These include the numerically dominant species (Stylatula 


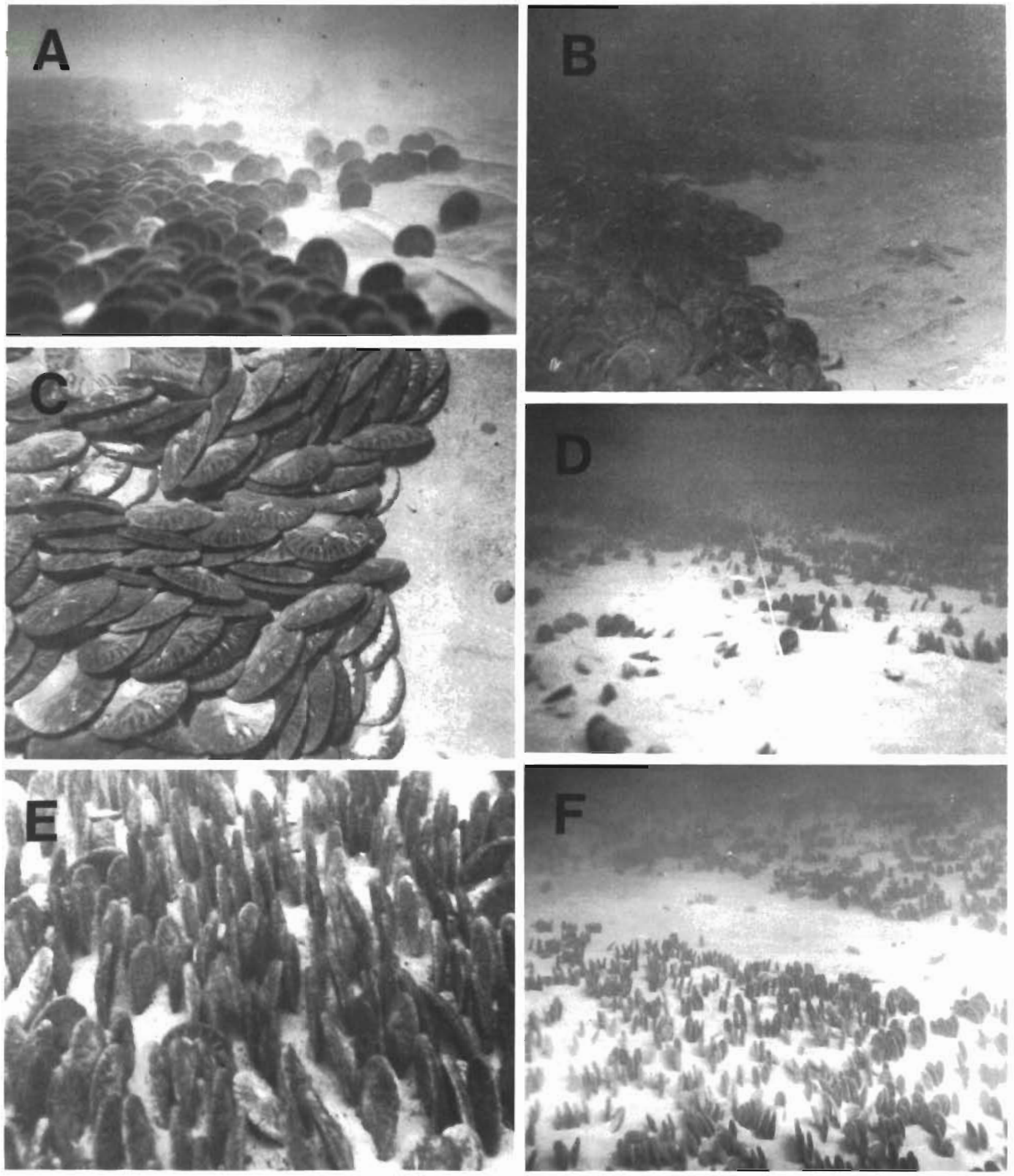

Fig. 5. Dendraster excentricus. Sand dollar aggregation. (A) Seaward edge of bed in winter (Dec); (B) Seaward edge of bed in summer (Aug); (C) close-up of seaward edge in summer (Aug); (D) shoreward edge of bed in winter (Dec), also showing the transect line; (E) close-up of central part of bed in spring (Mar); (F) central part of bed in fall (Nov) showing a 'hole' devoid of sand dollars 


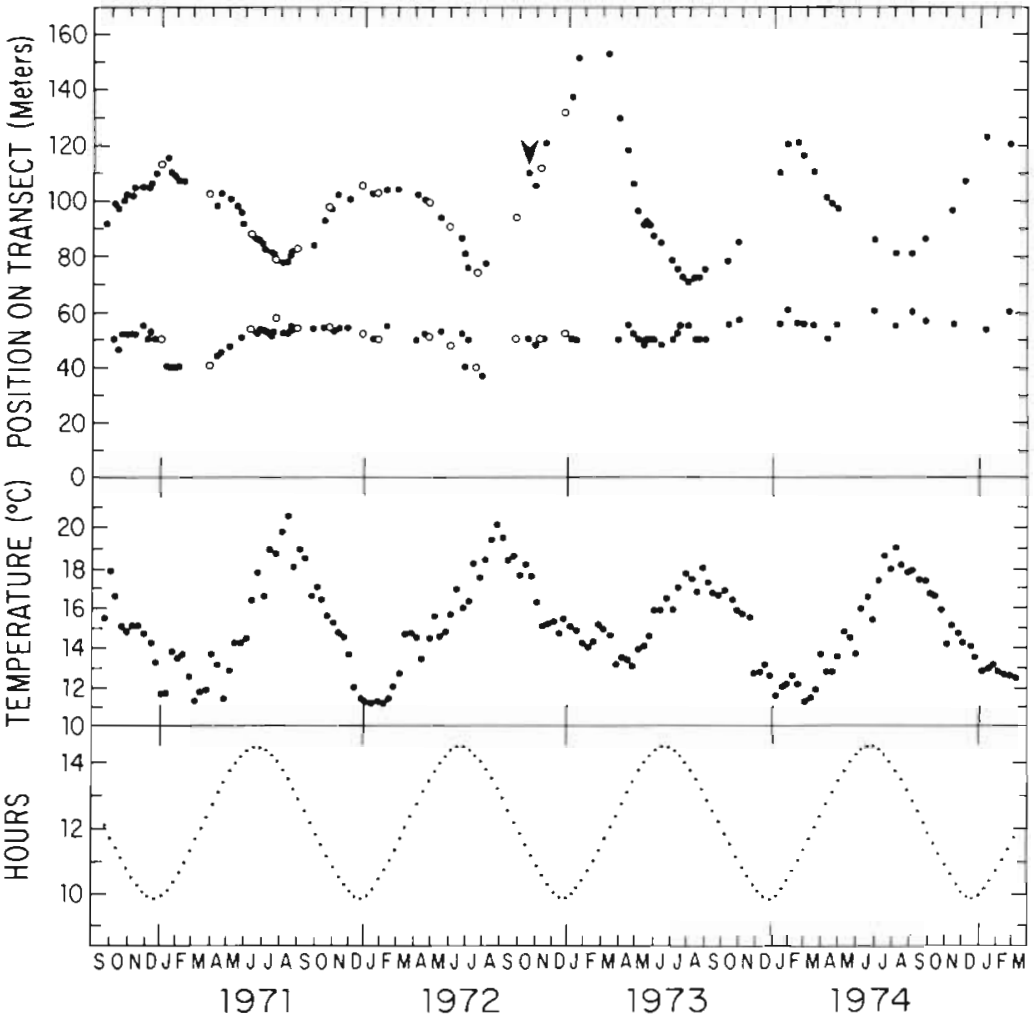

Fig. 6. Dendraster excentricus. Movement of sand dollar bed compared to sea temperature and day length. Upper: the location of the seaward (top circles, $>70 \mathrm{~m}$ ) and shoreward (bottom circles, $<60 \mathrm{~m}$ ) edges of the sand dollar bed along the transect through time. Open circles indicate the sand dollar densities plotted in Fig. 7. Arrow indicates storm-influenced seaward dispersion followed by a shoreward movement succeeded by additional seaward movement. Middle: temperatures (each an average of $10 \mathrm{~d}$ with 1 to 3 readings $\mathrm{d}^{-1}$ ) at the sea surface through time (data supplied by the Los Angeles County Lifeguards at Zuma Beach). Bottom: day length through time (data taken from NOAA Tide Tables) elongata and Astropecten verrilli), the gastropods Polinices altus and Megasurcula carpenteriana, the sand star Luidia ( $=$ Petalaster) foliolata, and the elbow crab Heterocrypta occidentalis.

The sand dollar bed expands to as deep as $11.4 \mathrm{~m}$ (the $150 \mathrm{~m}$ transect mark) during winter (see below); once the bed extends beyond the $9.1 \mathrm{~m}$ depth contour, Zone 3 organisms are in contact with the dense aggregation of sand dollars. In order to examine the possible effects of the movement of the high density, seaward edge of the sand dollars on the various species found within and beyond the bed, the distribution of certain animals was replotted with respect to this outside edge of the sand dollar bed (Fig. 8). Three types of patterns are revealed from these plots. (1) No changes in distribution correlated with changes in the distribution of the sand dollar population (neutral effect), as shown by the sea pen Stylatula elongata. (2) A truncation of the species' shoreward distribution at the outer edge of the sand dollar bed (possible exclusion [competitive] effect), as shown by Renilla kollikeri (see also Kastendiek 1982), the sea star Astropecten verrilli, the snails Polinices altus and Megasurcula carpenteriana, the nudibranch Armina californica, and probably the sea star Luidia foliolata and the crab Heterocrypta occidentalis. (3) A maximum density of the species' distribution at or near the outer edge of the sand dollar bed (potential enhancement or positive effect), as shown by animals that are usually associated with sand dollars either as a substrate, refuge or food source (Fig. 8). These include the sea stars Pisaster brevispinus, $P$. giganteus, and Astropecten armatus, and the snail Balcis rutila.

\section{Zonation of crabs and fishes}

Most of the crabs and fishes (e.g. Citharichthys stigmaeus, Fig. 3) show a fairly even distribution over depth within the study site. These animals show relatively low densities, high degrees of motility (Fig. 3 legend), often distinct nocturnal activities (see below, Table 2), and wariness of divers. Hence it was difficult to collect a sufficient number of observations within the $1 \mathrm{~m}$ wide transects to give reliable data on their distributions. The following animals are evenly distributed throughout all depths and zones within the study site: the crabs Cancer gracilis and Randallia ornata, and the fishes Platyrhinoidis triseriata, Citharichthys stigmaeus (Fig. 3), Pleuronichthys coenosus, Hypsopsetta guttulata and Paralichthys californicus. Although not statistically significant (low numbers), the sheep crab Loxorhynchus grandis is slightly more abundant within the sand dollar bed and the hermit crab Isocheles pilosus appears to be most abundant in the vicinity of the outside edge of the sand dollar bed. 


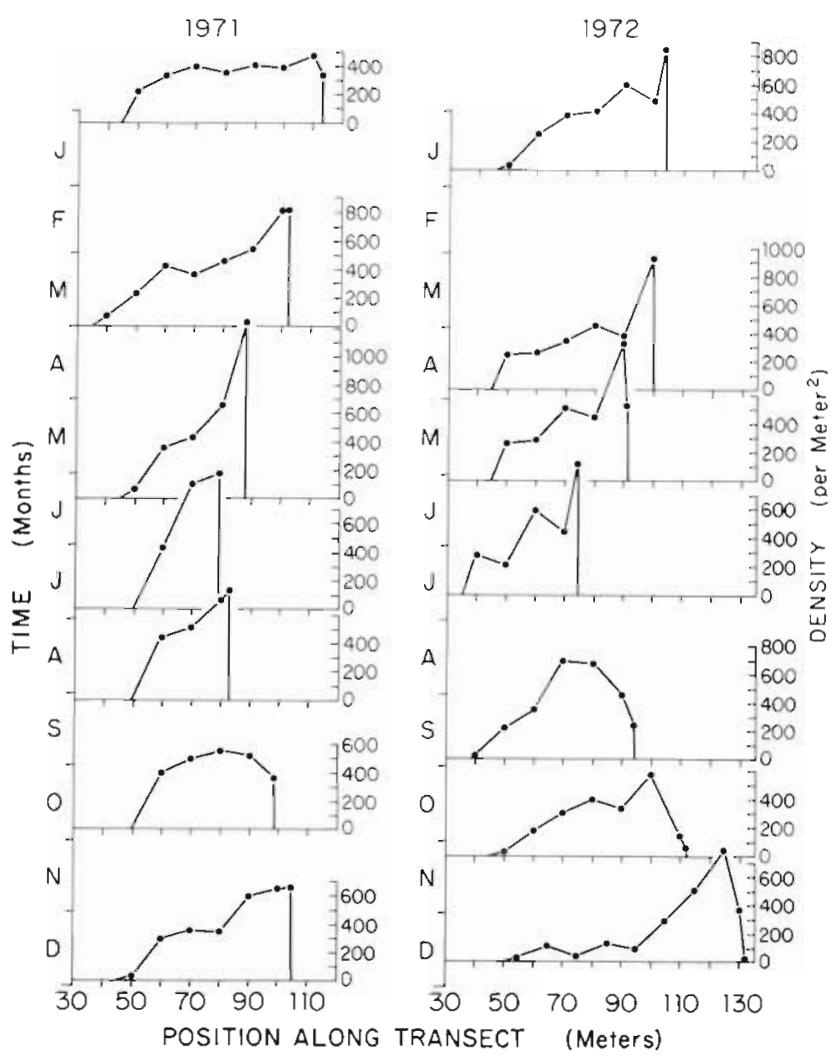

Fig. 7. Dendraster excentricus. Density of sand dollars $\left(\mathrm{m}^{-2}\right)$ in $10 \mathrm{~m}$ increments along the combined transect (in $\mathrm{m}$ ) at different times of the year at Zuma Beach. Densities are given to the right and time of year is plotted to the left. These data are taken from the open circles in Fig. 6 . Note the abrupt margins, the migration of the seaward margin with time, and the 'pile-up' along the seaward edge as the bed moves shoreward in the spring

\section{Seasonal changes}

The most striking long-term seasonal change is a predictable active 'migratory' expansion and contraction of the sand dollar bed (Fig. 6). In late summer (the last week of July or the first week of August) the seaward margin of the sand dollar bed is closest to shore at approximately the 70 to $80 \mathrm{~m}$ mark on the transect ( 7 to $8 \mathrm{~m}$ in depth). The bed then begins a gradual seaward expansion during the fall until it reaches its maximum seaward extent in January. The maximum seaward position varied considerably in each of the years it has been monitored (Fig. 6), from $105 \mathrm{~m}$ in January 1972 (with a resulting net movement of only $27 \mathrm{~m}$ from July 1971) to $155 \mathrm{~m}$ in January 1973 (with a comparable net movement of $78 \mathrm{~m}$ from July 1972). In January each year the seaward margin begins to move shoreward toward its retracted summer position. Throughout this annual 'migration' the cohesive wall-like appearance of the outside edge is maintained

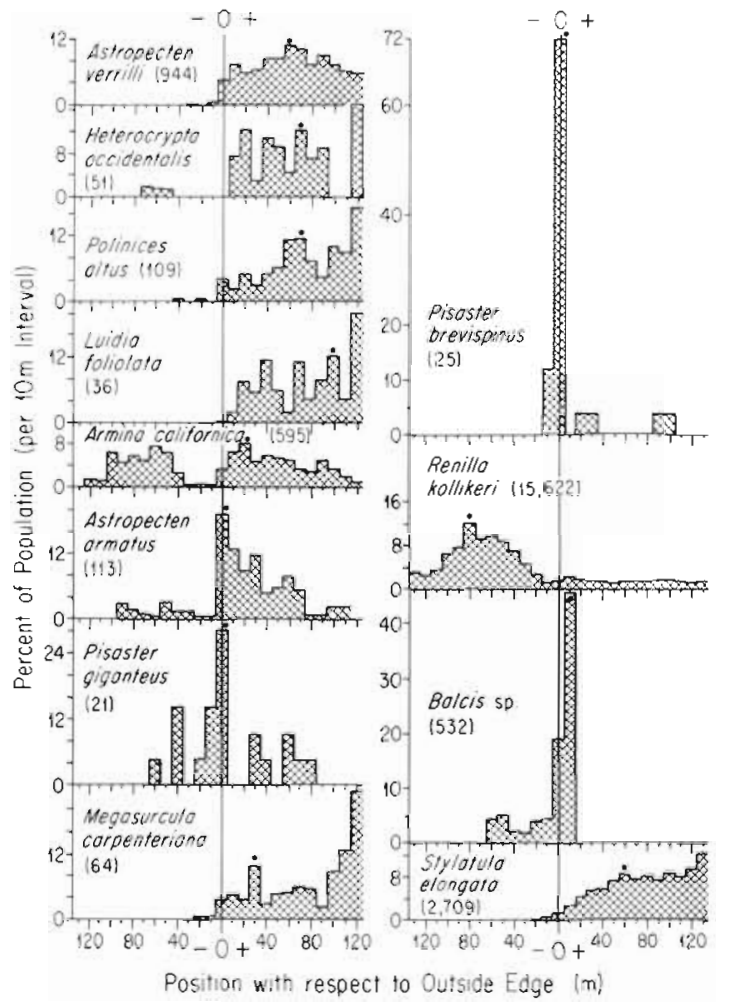

Fig. 8. Distribution of some of the common animals at Zuma Beach relative to their position with respect to the seaward (outside) edge of the sand dollar bed at all times of the year. Any individual encountered within 0 to $5 \mathrm{~m}$ of either side of this outside edge was recorded as $0 \mathrm{~m}$. Each $10 \mathrm{~m}$ increment seaward was plotted as positive $(+)$ from this 0 point and shoreward was similarly plotted but as negative $(-)$. Distributions are given as \% of the total population per $10 \mathrm{~m}$ interval. Plots show either an enhancement at the edge, a truncation on 1 side, or no effect. The total number of individuals evaluated for each species is given in parentheses. Density indicated at (.) is (in no. $100 \mathrm{~m}^{-2}$ dive $^{-1}$ ): Astropecten verrilli: 24.88; Heterocrypta occidentalis: 3.64 ; Polinices altus: 5.15 ; Luidia foliolata: 3.08; Armina californica: 11.70 ; Astropecten armatus: 5.45 ; Pisaster giganteus: 0.500 (per $10 \mathrm{~m} \times 100 \mathrm{~m}$ area); Megasurcula carpenteriana: 2.56; Pisaster brevispinus: 1.500 (per $10 \mathrm{~m} \times 100 \mathrm{~m}$ area); Renilla kollikeri: 508.0; Balcis rutila: 28.2 (100 sand dollars) ${ }^{-1}$; Stylatula elongata: 60.18

(Fig. 5 \& 7). The sand dollars actively move, primarily in the inclined position, and the whole outer seaward edge may move up to $3 \mathrm{~m} \mathrm{~d}^{-1}$ (an average of 0.57 $\mathrm{m} \mathrm{d}^{-1}$ in 1973; see Fig. 6). Although generally unaffected by surge, the outer edge can be altered significantly by very heavy surge. In September 1972, a $4 \mathrm{~m}$ surf resulted in a $30 \mathrm{~m}$ seaward movement of the seaward edge within $3 \mathrm{~d}$. In the $2 \mathrm{wk}$ following the subsidence of this large surf, the seaward edge moved back shoreward about $9 \mathrm{~m}$ prior to resuming its seaward migration (Fig. 6, arrow).

On the other hand, the shoreward (inner) edge of the sand dollar bed moves far less between seasons than 
does the seaward edge (Fig. 6). The net movement is less than $15 \mathrm{~m} \mathrm{yr}^{-1}$ and is apparently passive, driven by prevailing surge. Its position tends to be quite variable within this range and shows no seasonal consistency. However, because of its proximity to the surf zone, surge conditions dramatically influence the position of this shoreward edge by scattering the sand dollars shoreward or burying them during heavy surf. A distinct edge returns within a few days after the subsidence of heavy surf. The location of this inner edge is approximately at the point where major sand displacements cease (Fig. 2).

As a result of the yearly contraction and expansion of the bed at its outer edge, there are fluctuations in the density of the sand dollars at any 1 position within the bed (Fig. 7). At the outer edge, highest densities are recorded during summer (up to $1200 \mathrm{~m}^{-2}$ ) and lowest during winter (about 500 to $600 \mathrm{~m}^{-2}$ ). Another spatial characteristic of the summer bed is the presence of large transient open patches of sand (Fig. 5). Although these patches may occur throughout the year, they are larger and more numerous during the summer.

As the seaward edge moves deeper in the fall, there is an overall reduction of the sand dollar density throughout the bed until the maximum bed width is reached in January (Fig. 7). By contrast, as the seaward margin begins its annual spring shoreward migration the densities do not increase uniformly throughout the bed. Instead, during the entire shoreward migration there is a marked increase of sand dollar densities at the seaward edge over that of the remainder of the bed (Fig. 7). This crowding is observed until the minimum width of the bed is achieved in late June. Organisms that are positively associated with the sand dollar bed also seasonally adjust their position with respect to the bed (Fig. 8).

Organisms from Zone 3 that are apparently excluded by sand dollars (Fig. 8), such as the errant gastropods Polinices altus and Megasurcula carpenteriana, the asteroids Astropecten verrilli and Luidia foliolata, and the crab Heterocrypta occidentalis, are found closer to shore during summer than in winter. These are the species that show a truncation of their distributions at the outer edge of the sand dollar bed and their shoreward movement corresponds with the shoreward movement of the seaward edge of the sand dollar bed (Fig. 8) to the point where it reaches the $100 \mathrm{~m}$ mark on the transect (9.1 $\mathrm{m}$ depth). At that point, the sand dollars continue their shoreward movement but there is no further shoreward occurrence of these gastropods, asteroids and crab. Hence, the data suggest that sand dollars limit some of the Zone 3 animals' shoreward distribution only during part of the year. Consistent with the apparent spatial competition between sand dollars and these snails, sea stars and crab during winter, are our observations that these errant forms have severe difficulties moving between or over the sand dollars.

Most of the other observed seasonal changes are in the overall abundances of particular species (Table 1):

Fall. The increase of Armina californica in October coincides with the appearance of young Renilla kollikeri, their preferred prey, along the inner two-thirds of the transect (see Kastendiek 1982). Fall also marks the period when the small sand anemone Halcampa sp. is most prevalent and when there is an influx of the bat star Patiria miniata (both mainly in Zone 3). Paralabrax clathratus, the kelp bass, becomes more common over the sand dollar bed during the late fall, winter and early spring; it is rarely observed there in the summer.

Winter. During the winter and on into spring there occurs an influx of gravid Cancer antennarius, $C$. anthonyi and $C$. productus. The pale eolid Cuthona divae is most often encountered in Zone 3 on Diopatra ornata tubes in winter

Spring. The sand star Luidia foliolata migrates into shallower water (into Zone 3) from beyond the transect mainly during the spring months but persists to some extent through the summer and fall until it nearly disappears in winter. The jellyfish Pelagia colorata is most prevalent in the water column in spring and early summer. The crabs Loxorhynchus grandis and Heterocrypta occidentalis are somewhat more common in the spring than other times.

Summer. Although present throughout the year the ectoparasite Balcis rutila is very common on sand dollars at the seaward edge of the sand dollar bed (Fig. 8) in the summer and least common in the fall. During late summer and early fall Hermissenda crassicornis is most often found in Zone 3 on Diopatra ornata tubes with hydroids. The brittle star Amphiodia occidentalis of Zone 3 becomes much more common in late summer and fall. Finally, the halibut Paralichthys californicus and the lizard fish Synodus lucioceps are more prevalent in the summer and early fall than at other times

\section{Diel changes}

The most striking diel change in behavioral and distributional patterns of the epifauna occurs in the increased activity of the motile crustaceans and fish at night (Table 2). The numbers of both individuals and species observed active on or just above the sand within the study area dramatically increased at night.

Fishes. The fishes within our study site can generally be divided into 3 primary classes with respect to diel activity: those observed (i.e. active) (1) only at night, (2) only by day, or (3) both night and day. (1) Nocturnally active fishes (Table 2), the fishes primarily 
Table 1. Seasona] density differences of organisms along the Zuma Beach transect during the 4 yr study

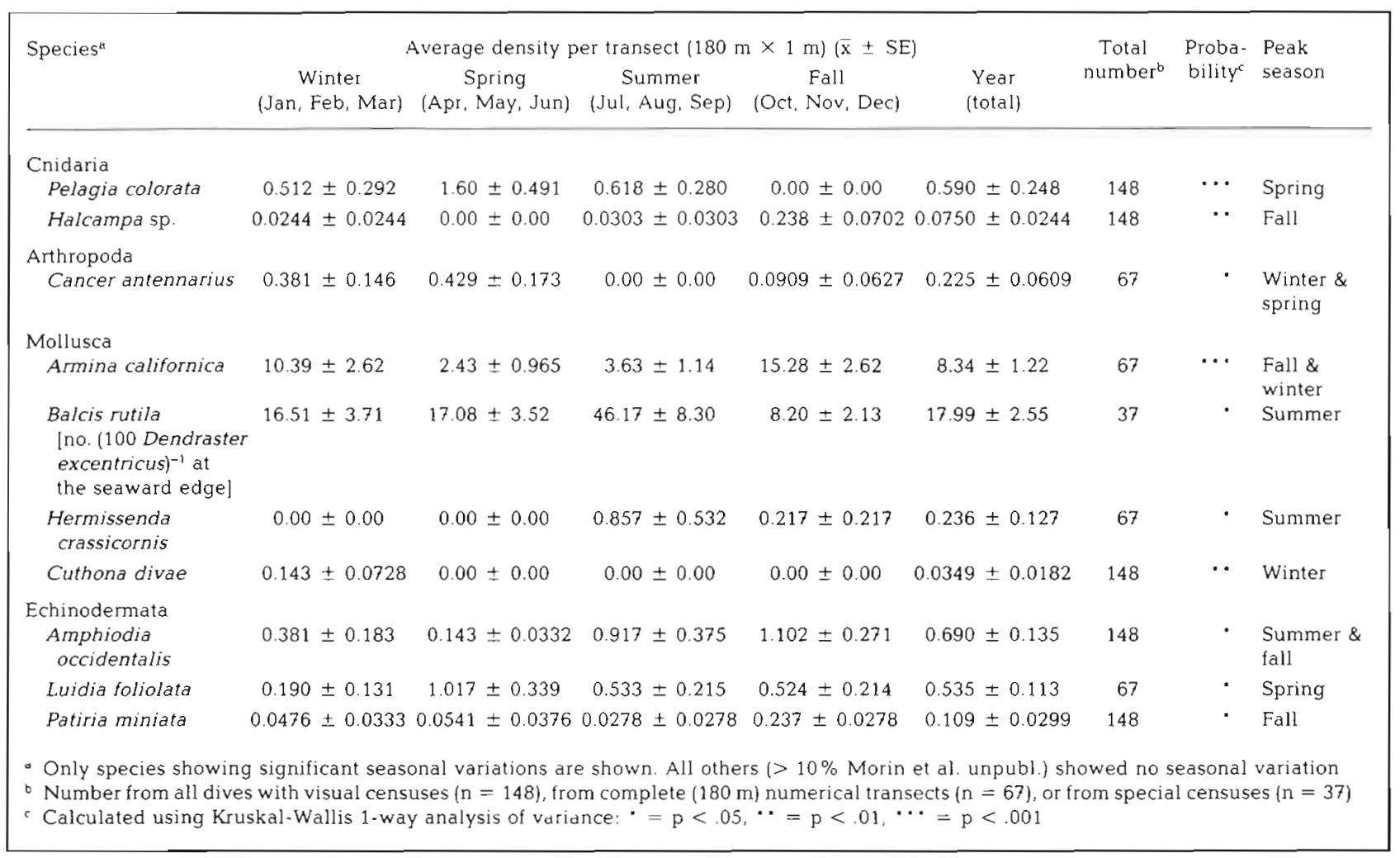

Table 2. Day-night density differences in nocturnally active crustaceans and fishes

\begin{tabular}{|c|c|c|c|}
\hline \multirow[t]{2}{*}{ Species } & \multicolumn{2}{|c|}{ Density (mean $100 \mathrm{~m}^{-2} \pm \mathrm{SE}$ ) } & \multirow[t]{2}{*}{ Probability } \\
\hline & Night $(\mathrm{n}=7)$ & $\operatorname{Day}(\mathrm{n}=7)$ & \\
\hline \multicolumn{4}{|l|}{ Crustaceans } \\
\hline Cancer gracilis & $2.19 \pm 0.554$ & $0.00 \pm 0.00$ & $\cdots$ \\
\hline Randallia ornata & $0.468 \pm 0.121$ & $0.0159 \pm 0.0159$ & $\cdots$ \\
\hline Portunus xantusii & $0.0873 \pm 0.0784$ & $0.00 \pm 0.00$ & $\mathrm{~ns}(\mathrm{P}<.2)$ \\
\hline Crangon nigricauda & $0.907 \pm 0.712$ & $0.00 \pm 0.00$ & $\cdot$ \\
\hline \multicolumn{4}{|l|}{ Fishes } \\
\hline Platyrhinoidis triseriata & $0.333 \pm 0.0918$ & $0.00794 \pm 0.00794$ & $\cdots$ \\
\hline Chilara taylori & $0.537 \pm 0.158$ & $0.00 \pm 0.00$ & $\cdots$ \\
\hline Leptocottus armatus & $0.315 \pm 0.108$ & $0.00 \pm 0.00$ & $\cdots$ \\
\hline Scorpaena guttata & $0.213 \pm 0.181$ & $0.00 \pm 0.00$ & ns $(\mathrm{P}<.09)$ \\
\hline Hyperprosopon argenteum & $0.333 \pm 0.164$ & $0.00 \pm 0.00$ & $\cdot$ \\
\hline $\begin{array}{l}\text { Data computed from } 7 \text { paire } \\
\text { Calculated using the Mann- }\end{array}$ & $\begin{array}{l}\text { transects. Each } \\
\text { Test: } \cdot=\mathrm{p}<.0\end{array}$ & $\begin{array}{l}\text { each pair was don } \\
<.01, \cdots=\mathrm{p}<.\end{array}$ & $\begin{array}{l}\text { of the other } \\
\text { ot significant }\end{array}$ \\
\hline
\end{tabular}

responsible for the dramatic increase in fish numbers at night are: the thornback Platyrhinoidis triseriata, staghorn sculpin Leptocottus armatus, walleye surfperch Hyperprosopon argenteum, and spotted cusk-eel Chilara taylori. Also more evident at night are the spotted scorpionfish Scorpaena guttata and shovelnose guitarfish Rhinobatos productus, although their numbers were too low to show significant diel changes in abundance. All of these species are rarely observed during the day within the study area. During the day $H$. argenteum occurs in small schools well off the bottom near the surfline (shoreward of our transects). 
At night they move close to the bottom and spread out as solitary individuals throughout the study area. They are nocturnal feeders (Ebeling \& Bray 1976, Hobson \& Chess 1976). The other nocturnally active fishes lie quiescent and well buried within the sand during the day and are therefore difficult to detect. All are very active and obvious at night. (2) Diurnally active fishes: along the sand bottom within our study sites there are relatively few strictly diurnal fishes. These include the perches Phanerodon furcatus and Damalichthys vacca. Neither species was encountered frequently, but when it was, the fish were in large mixed schools moving over the bottom actively 'picking' at the sand during the day. The kelp bass Paralabrax clathratus is occasionally encountered near the bottom during the day in the winter. We have not observed any of these fishes at night within the study area. (3) Fishes that are always present: as a group, the flat-fishes, including Citharichthys stigmaeus, Pleuronichthys coenosus and Hypsopsetta guttulata, do not vary much in occurrence with respect to the time of day. None showed statistically significant differences between day and night (Kruskal-Wallis 1-way analysis of variance). However, $P$. coenosus and $H$. guttulata appear to be completely uncovered from the sediment and active at night, but quiescent and partly buried during the day. There is no apparent change in numbers or activity of C. stigmaeus between day and night.

Arthropods. Since there appear to be no strictly diurnal crustaceans within our study site, the crustaceans can be divided into 2 classes: (1) always present, or (2) evident only at night. (1) Those always present: the anomurans Isocheles pilosus, Paguristes bakeri and Pagurus ochotensis, and the brachyurans Loxorhynchus grandis and Heterocrypta occidentalis appear active regardless of the light levels (Kruskal-Wallis 1way ANOVA; $p>$.05). (2) Those evident at night (Table 2): there is a massive increase in the numbers of larger crustaceans active at night. The crabs Cancer gracilis and Randallia ornata, and the shrimp Crangon nigricauda are strongly nocturnal and are buried during the daylight hours (Table 2). The brachyurans Portunus xantusii, Cancer antennarius, Cancer anthonyi and Cancer productus also show a similar pattern (but statistically insignificant due to low numbers), as does the anomuran sand crab Blepharipoda occidentalis. During the day, any of these crustaceans may sometimes be seen out foraging, especially if the light level is low due to heavy cloud cover or very turbid water.

There are also major qualitative differences between day and night among the small epibenthic crustaceans. Only mysids are observed swimming just off the bottom during the day However, during the night small ostracodes, amphipods, isopods, cumaceans and mysids occur in large numbers on or just above the sand surface. During the day all but the mysids are buried in the sand.

Dives made during the evening crepuscular period indicate that the diurnal-nocturnal switch in fish and arthropod distributions and activities begins to occur near sunset. However, this change can take place earlier if the sky is overcast.

Other members of the community, particularly the dominant sedentary members (Dendraster excentricus, Renilla kollikeri, Tivela stultorum and Stylatula elongata) and the motile gastropods and asteroids, show no obvious diurnal or nocturnal shifts of their basic patterns or numbers. However, the observation that there is no overt change in activity clearly does not preclude the possibility of more subtle alterations of these organisms. For instance, some of our observations suggest that the motility and/or activity of at least Armina californica, Astropecten spp., Luidia foliolata and Stylatula elongata may increase at night.

Both the numbers of active individual animals and the number of active species are greater at night than during the day. The source areas of the 'night' animals can be either deeper water, the substrate of the area itself, or the surf zone shoreward of Zone 1. All of the crustaceans emerge from the sand in which they have been buried during the day. Some of the fish (e.g. Chilara taylori) do the same, but some (e.g. Platyrhinoidis triseriata and Leptocottus armatus) may both be buried in the sand and/or come from other areas outside of the transect area. No measurements of the possible increase in potential prey items, which probably underlies this day-night phenomenon, have been made, although the numbers of small demersal crustaceans all increase perceptibly at night.

\section{Non-cyclic changes}

\section{Effects of sea conditions}

One effect of increased amplitude of the swell striking the beach is to increase the force of the wave surge along the entire depth gradient. The most apparent effect of strong surge (greater than about $2 \mathrm{~m} \mathrm{~s}^{-1}$ ) is a general active burrowing into the sand by many species; passive burial by shifting sand can augment this movement. By burrowing under the sand in heavy surf (>1.5 m) conditions, the entire sand dollar bed will virtually disappear. Renilla kollikeri, Stylatula elongata, Astropecten spp., the snails and most of the crabs will also burrow or be buried under the sand. Only the crab Loxorhynchus grandis, the asteroid Pisaster brevispinus and the various flatfishes remain at least partly exposed during these periods. The overall effect of reduced bottom wave surge activity throughout the 
transects (surf $<0.5 \mathrm{~m}$ ) is an emergence of most epifaunal species and also general movement of the motile components shoreward. These movements have been noted particularly for the nudibranch Armina californica and the starfish Astropecten armatus (see Kastendiek, 1982).

\section{Long term modifications in populations}

Long-term changes in the population sizes of some of the animals within the study area have been recorded during the period of this study (Table 3 ). The most dramatic non-seasonal variations have occurred with the erratic successful recruitment of juvenile Renilla kollikeri and Stylatula elongata (Table 3). These organisms release their gametes in the summer and the first small juveniles ( 1 to $3 \mathrm{~mm}$ ) can be detected visually on the bottom in September. No recruitment of $R$. kollikeri was detected in the fall of 1969 or 1970. In the fall of 1971 there was an extensive settlement of $R$. kollikeri larvae both in Zone 1 and in the shoreward part of Zone 3 (this increase becomes evident in 1972 in Table 3). No further recruitment was observed in the fall of 1972 or 1973. However, another substantial successful recruitment occurred in the fall of 1974 (see also Kastendiek 1982). Armina californica population fluctuations closely coincided with, but followed a few weeks after, the successful recruitment of their $R . \mathrm{kol}$ likeri prey in the fall of 1971 and 1974 (Table 3; see also Kastendiek 1982). The changes in S. elongata show a temporally different non-seasonal pattern of successful recruitment from $R$. kollikeri. Successful recruitment of $S$. elongata was extensive in both the fall of 1972 and 1973 (shown by major population increases in 1973 and 1974 respectively, Table 3), but not in 1970,1971 or 1974 . Other significant increases in populations were observed in the anemone Harenactis attenuata and especially the brittle star Amphiodia occidentalis; both showed a major gain in 1974 (Table 3). A single major population peak of Pelagia colorata occurred in the spring of 1972.

Diopatra ornata showed a decrease from 1971 to 1972 and then a significant $(\mathrm{p}<.05$, Kruskal-Wallis 1 way ANOVA) increase in 1974 (Fig. 3). However, this increase occurred only in Zone 3 and there was a decrease in Zone 2. The shoreward peak extended from about the $50 \mathrm{~m}$ to the $120 \mathrm{~m}$ position along the transect in winter 1971 (see Fig. 3), from about the $50 \mathrm{~m}$ to the $80 \mathrm{~m}$ position in winter 1972, and had disappeared almost entirely by the winter of 1973 and 1974 (Fig. 3). This gradual restriction of the peak coincided with the greater minimum shoreward position of the sand dollar bed from 1971 through 1973 (Fig. 6).

Decreases in population numbers between 1971 and
1974 were evident in the sand dollars and most of the snails found in Zone 3 and the crabs (Table 3). The Dendraster excentricus population showed a significant steady decline in numbers by over $40 \%$ between 1971 and 1974. All of the crabs showed a general decrease (although some not significant, Table 3) between 1971 and 1974. However, there was a dramatic increase in the number of Loxorhynchus grandis, Cancer gracilis and Randallia ornata in 1975. The Zone 3 snails showed a general but not significant decrease between 1972 and 1974 .

Among the other numerically dominant organisms (i.e. the remaining Zone 1 and 2 organisms, the asteroids and the fishes), no significant changes were detected in their populations during the course of the study.

\section{DISCUSSION}

\section{Zonation}

Zonation is well documented for intertidal and subtidal hard substrates (e.g. Pequegnat 1966, Dayton et al. 1970, Stephenson \& Stephenson 1972, Goldberg 1973, Kinzie 1973) and, to a lesser extent, intertidal and subtidal sands (Hedgpeth 1957, Fager 1968, Oliver et al. 1980). To these we can add the subtidal surge swept sand community; our study clearly demonstrates that distinct zones occur with depth along the changing stress gradient (also Morin et al. unpubl.). The zonation persists in spite of the shifting and unstable substrates, the general overall motility of the members, and the regular massive movements of the sand dollars. As with rocky (Stephenson \& Stephenson 1972) and sandy (Hedgpeth 1957) intertidal habitats, the presence of a subtidal zonation on such relatively simple sand habitats will probably be shown to be quite universal throughout the world.

The exposed shallow subtidal sand environment between a depth of 2.4 to and beyond $13 \mathrm{~m}$ at Zuma Beach along coastal California can be sorted into 3 distinct and dynamically interacting biological zones. The shallowest zone (2.4 to $6.5 \mathrm{~m}$ depth) is a physically stressful habitat characterized by almost continual sweeping and shifting sands churned up by strong, fluctuating wave surge; the bottom is often obscured by suspended sand. This is a biologically sparse zone inhabited only by burrowing and/or well anchored species that are hydrodynamically streamlined. The middle zone (6.4 to $9.1 \mathrm{~m}$ depth) commences where major sand shifting ceases (ca $6.5 \mathrm{~m}$ depth) and is a region of reduced turbulence but with still noticeable surge and some sand movement, but no major shifts in sand depth. It is dominated both numerically and 
Table 3. Population variation over a 4 yr period (1971 through 1974: includes only years with complete seasonal surveys)

\begin{tabular}{|c|c|c|c|c|c|c|c|c|}
\hline \multirow[t]{2}{*}{ Species ${ }^{a}$} & \multicolumn{5}{|c|}{$\begin{array}{l}\text { Average density per transect }(180 \mathrm{~m} \times 1 \mathrm{~m}) \\
\qquad(\overline{\mathrm{x}} \pm \mathrm{SE})\end{array}$} & \multirow[t]{2}{*}{$\begin{array}{l}\text { Total } \\
\text { number }\end{array}$} & \multirow[t]{2}{*}{$\begin{array}{l}\text { Proba- } \\
\text { bilityc }\end{array}$} & \multirow[t]{2}{*}{ Trend } \\
\hline & 1971. & 1972 & 1973 & 1974 & Total & & & \\
\hline \multicolumn{9}{|l|}{ Cnıdaria } \\
\hline Renilla kollikeri & $146 \pm 8.80$ & $345 \pm 65.5$ & $300 \pm 46.5$ & $231 \pm 36.4$ & $234 \pm 21.3$ & 40 & $\because$ & $\begin{array}{l}\text { Significant } \\
\text { peak in } 1972\end{array}$ \\
\hline $\begin{array}{l}\text { Stylatula } \\
\text { elongata }\end{array}$ & $32.5 \pm 5.22$ & $31.2 \pm 9.26$ & $474 \pm 8.22$ & $60.8 \pm 10.57$ & $39.3 \pm 3.96$ & 40 & $\cdot$ & $\begin{array}{l}\text { Significant } \\
\text { increase }\end{array}$ \\
\hline $\begin{array}{l}\text { Harenactis } \\
\text { attenuata }\end{array}$ & $0.0638 \pm 0.0472$ & $0.167 \pm 0.0674$ & $0.160 \pm 0.0945$ & $0.450 \pm 0.170$ & $0.172 \pm 0.0417$ & 135 & • & $\begin{array}{l}\text { Significant } \\
\text { increase }\end{array}$ \\
\hline Pelagia colorata & $0.173 \pm 0.0979$ & $0.833 \pm 0.250$ & $0.00 \pm 0.00$ & $0.0500 \pm 0.0500$ & $0.333 \pm 0.0907$ & 135 & $\cdots$ & $\begin{array}{l}\text { Significant } \\
\text { peak in } 1972\end{array}$ \\
\hline \multicolumn{9}{|l|}{ Arthropada } \\
\hline Isocheles pilosus & $0.286 \pm 0.122$ & $0.368 \pm 0.137$ & $0.167 \pm 0.112$ & $0.0833 \pm 0.0833$ & $0.250 \pm 0.0630$ & 64 & $\begin{array}{c}\mathrm{ns} \\
(\mathrm{P}<.5)\end{array}$ & $\begin{array}{l}\text { Gradual } \\
\text { decrease }\end{array}$ \\
\hline Cancer gracillis & $1.238 \pm 0.408$ & $0.632 \pm 0.326$ & $0.167 \pm 0.112$ & $0.0833 \pm 0.0833$ & $0.641 \pm 0.178$ & 64 & $\cdot$ & $\begin{array}{l}\text { Significant } \\
\text { decrease }\end{array}$ \\
\hline $\begin{array}{l}\text { Heterocrypta } \\
\text { occidentalis }\end{array}$ & $1.095 \pm 0.300$ & $1.158 \pm 0.407$ & $0.00 \pm 0.00$ & $0.0833 \pm 0.0833$ & $0.719 \pm 0.167$ & 64 & $\cdots$ & $\begin{array}{l}\text { Significant } \\
\text { decrease }\end{array}$ \\
\hline $\begin{array}{l}\text { Loxorhynchus } \\
\text { grandis }\end{array}$ & $0.592 \pm 0.172$ & $0.391 \pm 0.0957$ & $0.185 \pm 0.0452$ & $0.200 \pm 0.0816$ & $0.388 \pm 0.0658$ & 135 & $\stackrel{\text { ns }}{(P<.2)}$ & $\begin{array}{l}\text { Gradual } \\
\text { decrease }\end{array}$ \\
\hline Randallia ornata & $0.837 \pm 0.238$ & $0.174 \pm 0.0645$ & $0.0741 \pm 0.0514$ & $0.00 \pm 0.00$ & $0.347 \pm 0.0867$ & 135 & $\cdots$ & $\begin{array}{l}\text { Significant } \\
\text { decrease }\end{array}$ \\
\hline $\begin{array}{l}\text { Cancer } \\
\text { antennarius }\end{array}$ & $0.429 \pm 0.130$ & $0.211 \pm 0.145$ & $0.167 \pm 0.112$ & $0.00 \pm 0.00$ & $0.234 \pm 0.0878$ & 135 & $\cdot$ & $\begin{array}{l}\text { Significant } \\
\text { decrease }\end{array}$ \\
\hline \multicolumn{9}{|l|}{ Mollusca } \\
\hline $\begin{array}{l}\text { Armina } \\
\text { californica }\end{array}$ & $11.29 \pm 2.38$ & $11.68 \pm 3.11$ & $5.08 \pm 1.96$ & $5.23 \pm 2.40$ & $9.05 \pm 1.36$ & 64 & $\cdot$ & $\begin{array}{l}\text { Significant } \\
\text { peak in } 1972\end{array}$ \\
\hline $\begin{array}{l}\text { Polinices } \\
\text { altus }\end{array}$ & $1.67 \pm 0.545$ & $2.32 \pm 0.588$ & $1.25 \pm 0.524$ & $1.08 \pm 0.383$ & $1.67 \pm 0.276$ & 64 & $\begin{array}{c}n s \\
(P<.5)\end{array}$ & $\begin{array}{l}\text { Gradual } \\
\text { decrease } \\
\text { after } 1972\end{array}$ \\
\hline $\begin{array}{l}\text { Megasurcula } \\
\text { carpenteriana }\end{array}$ & $1.429 \pm 0.281$ & $0.947 \pm 0.209$ & $0.833 \pm 0.271$ & $0.692 \pm 0.237$ & $1.031 \pm 0.132$ & 64 & $\begin{array}{c}\text { ns } \\
(\mathrm{P}<.5)\end{array}$ & $\begin{array}{l}\text { Gradual } \\
\text { decrease }\end{array}$ \\
\hline $\begin{array}{l}\text { Terebra } \\
\text { pedroana }\end{array}$ & $0.321 \pm 0.100$ & $0.581 \pm 0.0895$ & $0.364 \pm 0.155$ & $0.100 \pm 0.0688$ & $0.377 \pm 0.0556$ & 135 & $\cdots$ & $\begin{array}{l}\text { Significant } \\
\text { decrease } \\
\text { after } 1972\end{array}$ \\
\hline $\begin{array}{r}\text { Nassarius } \\
\text { fossatus }\end{array}$ & $0.173 \pm 0.0597$ & $0.190 \pm 0.0702$ & $0.00 \pm 0.00$ & $0.00 \pm 0.00$ & $0.126 \pm 0.0323$ & 135 & $\begin{array}{c}\text { ns } \\
(P<.1)\end{array}$ & $\begin{array}{l}\text { Decrease } \\
\text { after } 1972\end{array}$ \\
\hline \multicolumn{9}{|l|}{ Echinodermata } \\
\hline $\begin{array}{l}\text { Dendraster } \\
\text { excentricus }\end{array}$ & $21430 \pm 1440$ & $17970 \pm 735$ & $16090 \pm 1260$ & $12620 \pm 673$ & $18200 \pm 677$ & 53 & $\cdots$ & $\begin{array}{l}\text { Significant } \\
\text { continuous } \\
\text { decrease }\end{array}$ \\
\hline $\begin{array}{l}\text { Amphiodia } \\
\text { occidentalis }\end{array}$ & $0.491 \pm 0.214$ & $0.438 \pm 0.174$ & $0.625 \pm 0.360$ & $2.476 \pm 0.635$ & $0.781 \pm 0.156$ & 135 & $\cdots$ & $\begin{array}{l}\text { Significant } \\
\text { increase }\end{array}$ \\
\hline $\begin{array}{l}\text { Astropecten } \\
\text { verrilli }\end{array}$ & $13.6 \pm 6.29$ & $13.7 \pm 4.00$ & $25.3 \pm 13.12$ & $18.1 \pm 3.96$ & $17.4 \pm 3.46$ & 64 & $\begin{array}{c}\mathrm{ns} \\
(p<.7)\end{array}$ & None \\
\hline A. armatus & $1.40 \pm 0.452$ & $2.67 \pm 0.362$ & $1.83 \pm 0.386$ & $2.33 \pm 0.386$ & $2.16 \pm 0.202$ & 64 & $\begin{array}{c}\text { ns } \\
(p<.2)\end{array}$ & None \\
\hline $\begin{array}{l}\text { Luidia } \\
\quad \text { follolata }\end{array}$ & $0.190 \pm 0.0878$ & $1.000 \pm 0.296$ & $0.500 \pm 0.323$ & $0.533 \pm 0.192$ & $0.552 \pm 0.118$ & 64 & $(p<.2)$ & None \\
\hline $\begin{array}{l}\text { Pisaster } \\
\quad \text { brevispinus }\end{array}$ & $0.0909 \pm 0.0627$ & $0.316 \pm 0.134$ & $0.167 \pm 0.112$ & $0.214 \pm 0.155$ & $0.194 \pm 0.0572$ & 64 & $(\mathrm{p}<.7)^{\mathrm{n}}$ & None \\
\hline P. giganteus & $0.136 \pm 0.0749$ & $0.316 \pm 0.110$ & $0.417 \pm 0.149$ & $0.214 \pm 0.155$ & $0.254 \pm 0.0576$ & 64 & $(p<.3)^{1}$ & None \\
\hline \multicolumn{9}{|c|}{ 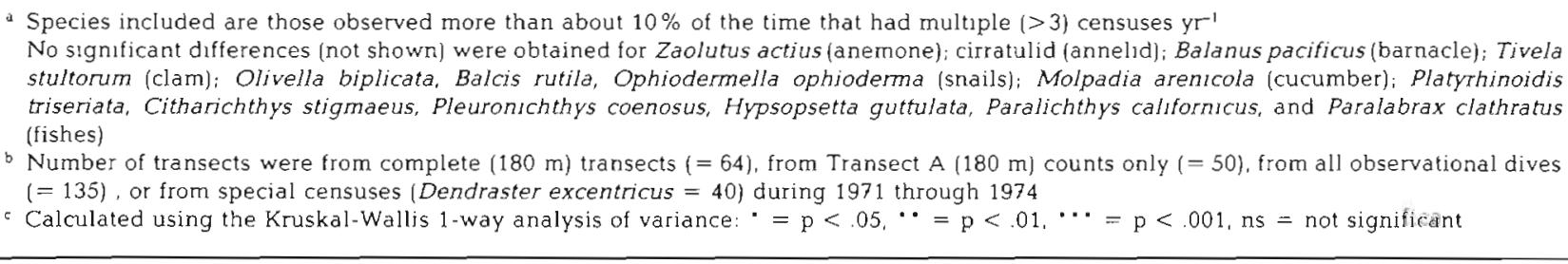 } \\
\hline
\end{tabular}


ecologically by the dense bed of sand dollars. This bed, by its dense packing and migratory patterns (see below), has a major impact on the distribution and activities of many of the organisms of the entire region. The deepest zone (>9.1 $\mathrm{m}$ depth) is relatively benign physically with reduced surge and almost no sand movement. It is a biologically diverse environment with numerous motile predators. In addition, in a primarily infaunal study, Oliver et al. (1980) have recognized another zonal break in still deeper water at about $14 \mathrm{~m}$ depth in Monterey Bay, California. They found small, motile, deposit-feeding crustaceans dominant at depths shallower than $14 \mathrm{~m}$ and suspension or surface deposit feeding tubicolous polychaetes dominant deeper than $14 \mathrm{~m}$.

\section{Numerical dominants}

The distinctiveness of each of the zones appears to be shaped and structured by the numerically dominant organisms: Tivela stultorum and Renilla kollikeri in Zone 1 (shallowest), Dendraster excentricus in Zone 2 (mid-depths), and Stylatula elongata, $R$, kollikeri, Astropecten verrilli and Diopatra ornata in Zone 3 (deepest). Most of these species (1) are sedentary suspension feeders, (2) are relatively large, (3) are quite long lived, (4) show sporadic successful recruitment, and (5) exhibit fairly low mortality as adults (Table 4).

\section{Feeding patterns}

Tivela stultorum, Renilla kollikeri, Dendraster excentricus and Stylatula elongata are sedentary suspension feeders and, by using special feeding structures, receive all or most of their food from the water column. The species replacements with depth within this sedentary suspension feeder guild show a trend of extending the feeding apparatus further into the water column as surge decreases (and depth increases). $T$. stultorum has the most shoreward distribution and is adapted to this turbulent area by being infaunal and collecting water with siphons held flush with the sand surface (Coe \& Fitch 1950). R. kollikeri, found immediately seaward of $T$. stultorum, extends its polyps a few $\mathrm{mm}$ into the water column (see also Kastendiek 1975). $D$. excentricus, when in its inclined suspension feeding posture, extends about 5 to $8 \mathrm{~cm}$ into the water column and is found in yet deeper water. The sand dollar obtains most of its food from suspended matter (Timko [= O'Neill] 1976, O'Neill 1978) but also deposit feeds (Chia 1969) during periods when lying flat on the bottom. This species may also take up dissolved organics (Stephens et al. 1978). In the deepest region of the study area, $S$. elongata extends up to ca $25 \mathrm{~cm}$ into the water column. Beyond the transects in still deeper water, ca 30 to $60 \mathrm{~m}$ depth, even longer sea pens (Acanthoptilum spp.) will be found extending up to nearly a meter into the water column (pers. obs.). As

Table 4. Characteristics of the numerical dominants

\begin{tabular}{|c|c|c|c|c|c|c|c|}
\hline \multirow[t]{2}{*}{ Species } & \multirow[t]{2}{*}{ Zone $^{a}$} & \multicolumn{2}{|c|}{ Size } & \multirow{2}{*}{$\begin{array}{l}\text { Maximum } \\
\text { age } \\
\text { (yr) }\end{array}$} & \multirow{2}{*}{$\begin{array}{c}\text { Density } \\
\text { (av. no. } \mathrm{m}^{-2} \\
\text { in zones of } \\
\text { occurrence) }\end{array}$} & \multirow{2}{*}{$\begin{array}{c}\text { Biomass } \\
\left(\text { av. } g \mathrm{~m}^{-2}\right)\end{array}$} & \multirow{2}{*}{$\begin{array}{l}\text { Successful } \\
\text { recruitment } \\
(y s)^{b}\end{array}$} \\
\hline & & $\begin{array}{l}\text { Approximate } \\
\text { av. diameter } \\
\text { or length (mm) }\end{array}$ & $\begin{array}{l}\text { Approximate } \\
\text { av. wet weight } \\
\text { (g) }\end{array}$ & & & & \\
\hline Tivela stultorum & 1 & $140^{\mathrm{c}}$ & $500^{c}$ & $45^{c}$ & 0.065 & 33 & None \\
\hline Dendraster excentricus & $2(3)^{d}$ & $60^{\mathrm{e}}$ & $12^{e}$ & $14^{\mathrm{e}}$ & 407 & 4884 & None \\
\hline Renilla kollikeri & $1,3,(2)$ & $80^{1}$ & $10^{f}$ & $>4^{1}$ & 1.3 & 13 & $\begin{array}{l}1971 \\
1974\end{array}$ \\
\hline Stylatula elongata & 3 & $150 \mathrm{~g}$ & $8^{g}$ & $>2^{g}$ & 0.37 & 3 & $\begin{array}{l}1972 \\
1973\end{array}$ \\
\hline Astropecten verrilli & 3 & $90^{\mathrm{h}}$ & $10^{\text {h }}$ & $>39$ & 0.16 & 2 & 1972 \\
\hline $\begin{array}{l}\text { Diopatra ornata } \\
\begin{array}{l}\text { a Fig. } 3 \\
\text { b See also Table } 3 \\
\text { c Coe \& Fitch } 1950 \\
\text { d Parentheses indicate } \\
\text { e Timko } 1975 \\
\text { ' Kastendiek } 1975 \\
\text { g Pers. obs. } \\
\text { h Davis } 1978\end{array}\end{array}$ & ne occup & $\begin{array}{c}100^{9} \\
\text { ed only part of th }\end{array}$ & e year or with re & $\begin{array}{c}- \\
\text { latively sma }\end{array}$ & $\begin{array}{r}2.2 \\
\text { II part of popu }\end{array}$ & $\begin{array}{c}11 \\
\text { lation isee } \mathrm{F}\end{array}$ & $\begin{array}{c}1973 \\
\text { g. } 3 \text { legend) }\end{array}$ \\
\hline
\end{tabular}


wave surge varies, all these animals are able to vary the amount of feeding surface exposed to the surrounding water without jeopardizing their stability in the sand. $T$. stultorum retracts its siphons beneath the sand under heavy surge conditions. $R$. kollikeri adjusts the height of its rachis as a function of flow velocity (Kastendiek 1976). Sand dollars stand upright under moderate surge, but during strong surge they lie down horizontally and burrow into the sand (Merrill \& Hobson 1970 , pers. obs.). S. elongata also appears to adjust its extension into the water column from only a $\mathrm{few} \mathrm{cm}$ during strong surge to fully extended during weak surge.

\section{General trophic relations}

Suspension feeding organisms tend to dominate the epifauna, especially in Zones 1 and 2 (Table 5). Carnivores and scavengers, especially gastropods and seastars, predominate in the deepest zone (3) and are relatively scarce in the 2 shoreward zones (Table 5 , Fig. 3). This trend towards a deeper water distribution of these motile predators results from the inability of these less hydrodynamically stable organisms to for- age in areas of high surge velocities (see Davis 1978, Kastendiek 1982, VanBlaricom 1982) and this physical limitation probably determines the nearshore boundary of Zone 3 at about $9 \mathrm{~m}$ depth (Fig. 3). Many of the more sedentary epifaunal and infaunal suspension feeders are specifically adapted to higher surge regimes, and therefore seem to have shallow water refugia from motile predatory or competing species. Pequegnat (1968) found a somewhat similar distribution on a subtidal rock outcrop; in biomass, suspension feeders dominated throughout but were most abundant in the shallowest depths while carnivores increased in abundance with depth. At Zuma Beach primary producers and grazing herbivores are almost non-existent in these shifting, unstable substrates. Deposit feeders are common but most of them, such as Molpadia arenicola, Macoma spp., and cirratulid polychaetes, are infaunal and not sampled in this survey (Morin et al. unpubl.). In still deeper waters (>14 m) at Monterey, Oliver et al. (1980) found that for the infauna, with depth, there was a decrease in motile individuals and a concomitant increase in sedentary individuals, which were primarily suspension and surface deposit feeding polychaetes.

Table 5. Species numbers, abundances, trophic relations and biomass by zones

\begin{tabular}{|c|c|c|c|c|c|c|c|}
\hline \multirow[t]{2}{*}{ Zone } & \multicolumn{2}{|c|}{ Species numbers ${ }^{a}$} & \multicolumn{2}{|c|}{$\begin{array}{l}\text { Percent of common } \\
\text { species which are: }\end{array}$} & \multirow{2}{*}{$\begin{array}{l}\text { Approximate } \\
\text { abundances } \\
\begin{array}{c}\text { (No. individuals } \\
\mathrm{m}^{-2} \text { ) }\end{array}\end{array}$} & \multirow{2}{*}{$\begin{array}{l}\text { Approximate } \\
\text { biomass } \\
\text { (g wet weight } \\
\mathrm{m}^{-2} \text { ) }\end{array}$} & \multirow{2}{*}{$\begin{array}{l}\text { Approximate } \\
\text { percent of } \\
\text { biomass as } \\
\text { suspension } \\
\text { feeders }\end{array}$} \\
\hline & $\begin{array}{l}\text { Total no. } \\
\text { of species } \\
\text { in zone }\end{array}$ & $\begin{array}{c}\text { No. of common } \\
\text { species in } \\
\text { zone }\end{array}$ & $\begin{array}{l}\text { Suspension } \\
\text { feeders }\end{array}$ & Carnivores & & & \\
\hline $\begin{array}{c}1 \\
(2.5 \text { to } 6.4 \mathrm{~m} \\
\text { depth })\end{array}$ & 9 & 3 & $67 \%$ & $0 \%$ & 2.7 & 60 & $98 \%$ \\
\hline $\begin{array}{c}2 \\
(6.4 \text { to } 9.1 \mathrm{~m} \\
\text { depth) }\end{array}$ & 32 & 12 & $33 \%$ & $50 \%$ & 409 & 4900 & $99 \%$ \\
\hline $\begin{array}{c}3 \\
\begin{array}{c}9.1 \text { to } 13.1 \mathrm{~m} \\
\text { depth) }\end{array}\end{array}$ & 66 & 20 & $20 \%$ & $70 \%$ & 3.9 & 25 & $31 \%$ \\
\hline $\begin{array}{l}\text { Species found } \\
\text { in all } \\
3 \text { zones }\end{array}$ & 32 & 18 & $6 \%$ & $89 \%$ & - & - & - \\
\hline $\begin{array}{l}\text { Total number } \\
\text { of species }\end{array}$ & 119 & 41 & $17 \%$ & $73 \%$ & - & - & - \\
\hline $\begin{array}{l}\text { a Morin et al. } \\
\text { b All species se } \\
\text { c Only those sp } \\
\text { d Calculated f } \\
\text { dividing by th } \\
\text { e Calculated fro } \\
\text { very approxin } \\
\text { Total of all or } \\
\text { and most of th }\end{array}$ & $\begin{array}{l}\text { by Morin } \\
\text { ies observed } \\
\text { totalling t } \\
\text { transect are } \\
\text { the abunda } \\
\text { ingms which } \\
\text { fishes and c }\end{array}$ & $\begin{array}{l}\text { al. unpubl. (A s } \\
\text { on }>10 \% \text { of the } \\
\text { e number seen } \\
\text { of the zone }(1 \mathrm{~m} \\
\text { ace column and } d \\
\text { occur roughly equ } \\
\text { abs }\end{array}$ & $\begin{array}{l}\text { pecies was co } \\
\text { dives (Morin } \\
\text { der dive of th } \\
\times \text { length of } \\
\text { ata in Table } 4 \\
\text { ually in all } 32\end{array}$ & $\begin{array}{l}\text { ted twice if } \\
\text { al. unpubl.) } \\
\text { common orga } \\
\text { ne): Zone } 1 \text { : } \\
\text { r other estim } \\
\text { les. Includes }\end{array}$ & $\begin{array}{l}\text { toccured in } 2 \text { zor } \\
\text { nisms in each zor } \\
55 \mathrm{~m}_{\text {; Zone } 2: 45} \\
\text { ates of biomass fro } \\
\text { Renilla kollikeri a }\end{array}$ & $\begin{array}{l}\text { nes) } \\
\text { ne (Morin et al } \\
\text { m; Zone } 3: 110 \\
\text { om pers. obs.). } \\
\text { and Armina call }\end{array}$ & $\begin{array}{l}\text { 1. unpubl.) and } \\
\mathrm{m} \\
\text { This estimate is } \\
\text { ifornica (Fig. 3) }\end{array}$ \\
\hline
\end{tabular}


Size, age, recruitment and mortality

All 6 of the dominant species represent a substantial standing crop of biomass where they occur. All are relatively long-lived (Table 4). Our data and others (Fager 1968, Timko 1975, Kastendiek 1975, 1982, Emerson 1976, Davis 1978, Davis \& VanBlaricom 1978, Cameron \& Rumrill 1982) indicate that successful recruitment is seasonal but sporadic, often missing 1 or more yr (Tables 3 \& 4). No significant successful recruitment was observed for Tivela stultorum and sand dollars between 1970 and 1975. Cameron \& Rumrill (1982) have shown that $D$. excentricus larvae vary from year to year in their abundance in the vicinity of a sand dollar bed and successful recruitment likewise varies. At Zuma Beach the only successful recruitment of sand dollars to the study area since at least 1969 occurred in the late summer of 1981 and 1982 (Morin pers. obs.). Major successful recruitment during 1 or 2 seasons appears responsible for sustaining the majority of the Renilla kollikeri populations for 4 or more yr (Kastendiek 1982) and Dendraster excentricus populations for 13 or more yr (Timko 1975, Morin pers. obs.).

Most of the dominant organisms apparently enjoy fairly low mortality from predation as adults. Probably the most important factor in maintaining low adult mortality for Renilla kollikeri, Tivela stultorum and Dendraster excentricus are the adaptations that allow them to exist in higher surge regimes than many of the predators. Thus they apparently have shallow water refugia from predation (e.g. see Davis 1978, Kastendiek 1982). Most also have special defenses against specific predators, $R$. kollikeri is preyed upon by Armina californica and Astropecten armatus but, in addition to the shallow water refugium, it possesses specific escape responses and is apparently only rarely consumed by either predator (Kastendiek 1976, 1982). When no successful recruitment occurred, the $R$. $\mathrm{kol}$ likeri population at Zuma Beach apparently suffered about a $13 \%$ mortality from 1972 to 1973 and a $23 \%$ mortality from 1973 to 1974 (Table 3). While it is probable that high predation rates occur in these populations at the time of metamorphosis and early postlarval stages, there appears to be a low mortality rate once they reach a size of about 1 to $2 \mathrm{~mm}$ (the size when they become easily detected and captured in our sieves). $T$. stultorum, Stylatula elongata, Diopatra ornata (see below), and Astropecten verrilli all showed low or sporadic successful recruitment and no detectable decreases during the study (Table 3). T. stultorum is known to be preyed upon by the deep water snail Forreria belcheri (pers. obs.) when it occasionally migrates in during the spring. However, this snail is rare and its occurrence in the shoreward zone is very unusual and restricted to periods of relative calm.
Mortality appears quite low after the early postlarval stages in Dendraster excentricus (Table 3). Known predators on these post-larval individuals are the sea stars Pisaster brevispinus and P. giganteus; the decapods Cancer gracilis, C. antennarius, C. productus, $C$. anthonyi, and Loxorhynchus grandis; the gastropod Balcis rutila, and the bat ray Myliobatis californica (MacGinitie \& MacGinitie 1949, Merrill \& Hobson 1970 , pers. obs.). B. rutila is an ectoparasite and does not usually destroy its prey. On the other hand, the presence of Balanus pacificus on D. excentricus causes hydrodynamic instability in the sand dollar and makes it susceptible to being carried into the surf zone and killed during storms (Merrill \& Hobson 1970). These factors probably collectively account for the observed mortality of approximately $13 \% \mathrm{yr}^{-1}$ (Table 3).

The net effect of these factors (large numbers and biomass, long life span, low successful recruitment and the apparent low predation rate) is a large standing crop but a very low turnover in and productivity of biomass.

Species numbers, abundances and biomass

The total number of species present in each zone increases from the shallowest to the deepest zones (Table 5). Such an increase in diversity along physical gradients that range from harsh to mild has been frequently observed (for review see Gray 1974, Rhoads 1974). The middle zone (2) with sand dollar densities up to $1200 \mathrm{~m}^{-2}$, and relatively large individual size (ca $12 \mathrm{~g}$ ) contains the greatest numbers of total individuals and total biomass. While the biomass of the infaunal organisms has been estimated from limited sampling, it is very small compared to that of sand dollars and other epifauna (T. E. Ronan unpubl.). The biomass peak at an intermediate depth and surge regime suggests that the sand dollar occupies a depth range optimal in terms of food availability relative to physical stress and biological interactions. In the deeper region diversity increases with the increased bottom stability but both abundances and biomass decrease, perhaps due to decreased availability of suspended food material and/or increased predation pressure. At depths shallower than the sand dollar bed, suspended food may be abundant but the severe physical conditions apparently limit abundances, biomass and diversity.

\section{The sand dollar bed}

Superimposed on the zonation, there are the dynamic effects of the migratory sand dollar bed. Sharply delineated dense aggregations of sand dollars Dendraster excentricus are common along the Pacific 
coast (Fager 1968, Chia 1969, Merrill \& Hobson 1970, Birkeland \& Chia 1971, Parks 1973, Timko 1975, 1976. 1979, O'Neill [= Timko] 1978, Niesen 1977, Dexter 1978, Davis \& VanBlaricom 1978, Oliver et al. 1980, Smith 1981, Highsmith 1982) and also occur among other clypeasteroids (Sokolova \& Kusnetzov 1960, Bell \& Frey 1969, Stanley \& James 1971, Ebert \& Dexter 1975, Dexter 1977).

The sand dollars within the bed stand on edge (inclined position) in a hydrodynamically stable state parallel to the wave surge and feed on suspended material (Timko 1975, 1976, O' Neill [= Timko] 1978; see also Telford 1981 for general hydrodynamic considerations). The high densities probably provide for mutualistic (or social) interactions between individuals (O'Neill 1978). O'Neill has shown that under laboratory conditions, close spacing of individuals in the inclined position in a current enhances their ability to feed on suspended material. She showed that at lower velocities, sand dollars must be spaced closer together to maintain a given mutual enhancement of feeding. Observations of the field aggregations at Zuma Beach support this laboratory finding. The lowest densities (and greatest distances between individuals) are found in the shallowest (highest surge velocity) regions. Conversely, the tightest packing (highest densities) occur in the deepest (lowest surge) regions. Furthermore, the highest overall densities occur in the summer when surge is seasonally minimal. Another factor that might be responsible in part for the high summer densities is the enhancement, by crowding, of successful fertilization during their July and August spawning seasons (Timko 1975, 1979).

The edges of the bed. The factor primarily responsible for dictating the shoreward location of the sand dollar distribution appears to be sand movement (compare Fig. 2 \& 3) and is thus largely responsible for the position of a break-point between 2 of the faunal zones of the community. The observation that, after transport into shallower water by heavy surge, sand dollars at Zuma Beach actively return to the deeper region where sand movement is negligible, also argues for their adverse response to increasing water and/or substrate movement. Further evidence that sand movement and wave surge rather than water depth may determine the position of the nearshore limit of sand dollar populations comes from their distributions in embayments, lagoons and sounds where they can be found in the shallow subtidal and lower intertidal (Birkeland \& Chia 1971, Timko 1975, Smith 1981, Highsmith 1982). Here currents are substantially lower than on the outer coast (Merrill \& Hobson 1970, Tirnko 1975). Finally, even in the deeper regions sand dollars will burrow under the sand whenever strong surge conditions prevail (Merrill \& Hobson 1970, pers, obs.).
The factors that influence the more distinct seaward margin of the sand dollar population are less clear. A predator, parasite, or competitive dominant may occur in the seaward zone during the spring and summer months, and move into deeper water or disappear during the fall and winter (e.g. Balcis rutila, Table 1). The bed moves out rather evenly with respect to its overall density during its fall seaward migration but has a seaward edge 'pile-up' during the spring shoreward migration (Fig. 7). This difference suggests the release of some limiting factor in the fall so that much of the sand dollar population moves seaward gradually and evenly, but during the spring only the most seaward individuals are affected and move toward shore, thus piling up on those shoreward of them. It could be that those individuals in a given location respond only as the 'factor' reaches shallower and shallower depths.

Pisaster spp., the bat ray Myliobatis californica, the snail Balcis rutila and several crabs prey upon sand dollars (see above). Of these, $P$. brevispinus, $P$. giganteus, and $B$. rutila are most frequently observed along the seaward margin of the bed (Fig. 8) and could potentially affect it. For instance, B. rutila abundance is substantial and is highest in the spring and summer (which fits the description of the 'factor' given above). Sand dollars show a marked burying and movement away from the presence of the sea stars $P$. brevispinus and $P$. giganteus (MacGinitie \& MacGinitie 1949, pers. obs.), but the densities of these stars are so low and sporadic that we cannot speculate whether they might be controlling factors (Fig. $3 \& 8$; Morin et al. unpubl.). Competitive interactions between sand dollars and other members of the community did not appear to be responsible for the distinct seaward margin and its movements.

There is an apparent correlation of the timing of the actual migration with day length (Fig. 6). Thus day length may be the proximate cause for the migrations. The annual fall seaward movement and spring shoreward movement are not directly correlated to changes in temperature since seasonal temperature changes often begin after the sand dollars have begun moving (e.g. the shoreward movements in 1971, 1973, 1974, 1975, and the seaward movement in 1972, Fig. 6). However, the movement of the bed always begins 3 to 6 wk after the winter and summer solstices, but never before it. A coupling of migrations to day length is well known to occur in other organisms, particularly insects and birds (e.g. Dingle 1972, Gwinner 1975). The functional significance of the migration might be a complex interplay to optimize feeding, to provide refugia from predators, and to enhance reproductive success. An expansion of the bed during the fall would tend to increase the distance between sand dollars (i.e. increase the optimal gap for feeding: O'Neill 1978), at 
a time when the ocean swells are generally becoming larger overall with the onset of the winter storms. However, the strongest surge usually occurs in the late winter and spring at a time when the sand dollars are migrating shoreward. This apparent contradiction might be explained by the reproductive requirements of the population. Since individual reproductive success is enhanced by high densities (Timko 1976 , O'Neill 1978) it may be that the reproductive benefits to the sand dollars overrides the feeding benefits during the spring shoreward migration. Furthermore, migration away from predators could act synergistically with this effect (see above). The factors controlling the maximum and minimum seaward extent of the migration are unknown. We have examined the physical data collected by the Los Angeles County Lifeguards at Zuma Beach (these data included: weather conditions, air and sea temperature, and surf height and direction) and have not found any single factor that correlates with the extent of the variation in bed width.

\section{Community interactions}

The impact that the sand dollar migration has on the surrounding community is significant both spatially and temporally. The shoreward boundary of most of the seaward zone (3) organisms apparently alternates between a fairly static physical shoreward limitation (at $9 \mathrm{~m}$ presumably due to wave surge) during the summer and a dynamic biological limitation (probably due to competition for space with sand dollars) during the winter. The results show that a competitive exclusion probably occurs with some but not all of the Zone 3 organisms. Sand dollars appear to exclude Renilla kollikeri and the motile organisms that crawl or plow along close to the sand: the gastropods Megasurcula carpenteriana, Polinices altus and Armina californica; the sea stars Astropecten spp. and Luidia foliolata; and the crab Heterocrypta occidentalis (Fig. 8). Kastendiek (1982) has experimentally shown that $R$. kollikeri, A. californica and Astropecten spp. are physically excluded by the presence of large numbers of sand dollars. Augmenting these data, our visual observations indicate that all 8 of these organisms have difficulty moving between or fitting among the sand dollars. On the other hand, except for $A$. californica and Astropecten armatus, these creeping organisms rarely penetrate shoreward to depths less than about $9.1 \mathrm{~m}$ (the boundary between Zones 2 and 3) presumably because they are susceptible to being tumbled and rolled by the increased surge and sand motion in these shallower waters (see above and Davis 1978, Kastendiek 1982, pers, obs.).

The net effect is an apparent dynamic exclusionary influence of the sand dollars during the winter superimposed on a somewhat constant physical limitation to the creeping organisms of Zone 3. As long as the sand dollar bed remains in Zone 3 it seems to exclude the creeping organisms from the shoreward margins of the zone (Fig. 8). Thus the effect that sand dollars have on the distribution of these organisms appears to vary considerably in extent both spatially (from about $5 \mathrm{~m}$ on the horizontal depth profile in 1972 to $55 \mathrm{~m}$ in 1973) and temporally (about $4 \mathrm{mo}$ in 1974 and $6 \frac{1 / 2}{2} \mathrm{mo}$ in 1973; compare Fig. 6 \& 8).

A few organisms appear to be unaffected by the presence or movements of the sand dollars. These include organisms: (1) small or narrow enough to exist between the sand dollars (e.g. Diopatra ornata, Stylatula elongata, Heptacarpus sp.) (neutral effect, Fig. 8); (2) infaunal and existing beneath the sand dollars (e.g. Molpadia arenicola); (3) epibiotic and attached to the sand dollars (e.g. Balanus pacificus and Balcis rutila); or (4) large enough to step or swim over the bed (e.g. the larger crabs and most of the fishes). The dominant long thin sessile suspension feeding organism in Zone 3, S. elongata, shows no apparent exclusion by the migrating sand dollars (Fig. 8). It shows a nearshore limitation at $9.1 \mathrm{~m}$ throughout the year and specimens of $S$. elongata are frequently observed among the sand dollars during the winter expansion into Zone 3. While we have little information on the effect of sand dollars on infaunal organisms, both Smith (1981) and Highsmith (1982) have demonstrated significant differences between infaunal populations inside and outside of sand dollar beds from the protected Puget Sound region. A similar situation may exist on exposed coasts (T. E. Ronan unpubl.).

Certain organisms are more abundant in the vicinity of the sand dollar bed (Fig. 8) and associate with it as: (1) a food source (e.g. the snail Balcis rutila and the sea stars Pisaster spp. and Astropecten armatus, which feeds only on small juveniles or pieces broken by crabs or fishes), (2) a substrate (e.g. the barnacle Balanus pacificus), or (3) a refuge (e.g. the shrimp Heptacarpus sp.).

The tube worm Diopatra ornata appears to show an interesting correlation with sand dollars that relates to potential sheltering effects from wave surge (Fig. 3). In $1971 \mathrm{D}$. ornata had a bimodal population distribution with peaks in both Zone 2 at a depth of about $8.5 \mathrm{~m}$ and Zone 3 at a depth of about $12.5 \mathrm{~m}$. The majority of the nearshore peak existed within the boundaries of the sand dollar bed. We suggest that this nearshore peak could persist in the relatively high surge regimes of Zone 2 only because of the protective damping of the bottom surge by the sand dollar bed itself. As this protection was removed from the seaward part of the $D$. ornata population by the contractions of the sand dollar 
bed in the summer in 1971 and 1972, the seaward portions of the Zone $2 D$, ornata population disappeared. The Zone 3 portions remained as did the shallowest (protected) part of the Zone 2 population. Presumably the more nearshore contraction of the sand dollar bed in the summers of 1971 and 1972 exposed the seaward regions of Zone 2 to unrestrained wave surge and the $D$. ornata in those areas were destroyed. As with most other Zone 3 organisms, however, beyond a depth of about $9.1 \mathrm{~m}$ wave surge apparently did not eliminate those $D$. ornata. Since the deeper dwelling $D$. ornata survived, it is also unlikely that predation was responsible for the observed decrease in Zone 2. Thus, the sand dollar bed appears to exhibit both a positive (protective) and negative (by exposure in its absence) effect on part of the $D$. ornata population at different times and yet seems to have had a neutral effect on the deeper individuals as the bed expanded past them each winter.

The summer barren zone. When the sand dollar bed is in its contracted 'pile on' state in late spring and summer there exists a faunistically depauperate region in outer Zone 2 between the edge of the bed (ca $7.5 \mathrm{~m}$ depth) and the beginning of Zone 3 in $9.1 \mathrm{~m}$ of water. Since organisms from Zone 3 are apparently excluded from this area by wave surge, and the sand dollars have migrated well shoreward, the area contains only low numbers of Renilla kollikeri and Diopatra ornata, a few Astropecten armatus and little else. The contrast is all the more pronounced because of the high sand dollar densities, often over $1000 \mathrm{~m}^{-2}$, just shoreward of this barren zone and high species diversity seaward of it. Thus, presumably because of increased surge, few epifaunal organisms appear capable of invading this vacant region from deeper water.

\section{Diel activity}

Distributions of many of the motile organisms within the sand bottom community change spectacularly from daylight to night-time (Table 2) and seem to be different from those associated with hard substrates. In the subtidal sand habitat the change can be viewed, not so much as replacement of elements from day to night typically seen with hard substrates, but as a dramatic and pronounced utilization of the sand surfaces only during the hours of darkness by the errant fishes, crabs, and small crustaceans. The pattern is similar to that generally shown by most demersal zooplankters (e.g. Alldredge \& King 1977, 1980, Porter \& Porter 1977). The 'one-sided' utilization of the habitat by fishes is very different from the diurnal-nocturnal activity patterns exhibited by reef fishes (Hobson 1965, 1972 , Hobson \& Chess 1976, Hobson et al. 1981, Collette \&
Talbot 1972, Ebeling \& Bray 1976) and temperate lake fishes (Emery 1973) that show a tendency for a more uniform replacement of diurnal fishes with noctural ones and vice versa. Apparently, in contrast to heterogeneous reef situations, the general homogeneity of the sand habitat surface does not provide sufficient diurnal protection from predators. Many of the motile species hide during the day by burrowing or moving to more protected locations. It is primarily the dominant suspension feeders and well protected foragers, which are relatively immune from predation, that are easily visible by day.

\section{Stability}

Fager (1968), in one of the few studies of a similar community, emphasized his unexpected findings concerning the long-term stability of the community. Of the 9 numerically dominant species of epifaunal invertebrates he stated 'the species composition of the community and the abundances of the individual species did not change over the $6 \mathrm{yr}$ period of study... However, Davis \& VanBlaricom (1978) studied the same community in the same location as Fager and used similar methods, but 'showed both long and short term fluctuations ... as well as physical and biological heterogeneity'. Our findings for a comparable habitat also demonstrate significant temporal and spatial fluctuations in some of the dominant populations (Table 3). Some populations did not change significantly during the study (sea stars, some molluscs and fishes), some decreased for 4 consecutive years then increased (the crabs and some snails), one (the dominant sand dollars) showed a persistent uniform decline throughout the study and no successful recruitment, some species recruited during only 1 yr of the study (anemone Harenactis attenuata, some snails, and the brittle star Amphiodia occidentalis), and only Renilla kollikeri, Stylatula elongata and Armina californica showed 2 recruitrnent episodes in 5 yr. No populations showed consistent annual successful recruitment. Thus, successful recruitment among the macroscopic epifauna appeared sporadic and variable over several years (Table 3).

On the other hand, while constancy in the sense of numerical abundance was not demonstrated, constancy in terms of the persistence of species was. Sudden changes in the abundances of the benthic species occurred but local extinction did not. Large, periodic successful recruitment is the main source of sudden increase in population size. The factors responsible for successful recruitment are not known. In a community of long-lived organisms with infrequent episodes of massive successful recruitment, stability is best mea- 
sured over many years rather than the few years of this study.

\section{CONCLUSION}

Studies of soft-bottom habitats have shown that a variety of factors affect the community structure, particularly the infauna. These factors include disturbance and refuges (Woodin 1978, 1981, Kastendiek 1982, VanBlaricom 1982), successful recruitment (Woodin 1974, Peterson 1977, Timko 1979), predation (Virnstein 1977, 1979, Wiltse 1980, Woodin 1981, VanBlaricom 1982), and competition (Woodin 1974, Peterson 1977, Peterson \& Andre 1980). Our data suggest that all of these factors have an influence on the shallow exposed sand epifauna, but there is a mosaic effect of where and when a given factor affects the community. The community appears to be simple enough that, through long term observations and natural experiments alone, we can detect the effects of successful recruitment, competition and predation. Furthermore, refuges seem to occur between seasons and between periods of calm and storm. The dominant organisms that strongly influence the community structure provide a matrix around which the remainder of the community is organized. These organisms (Dendraster excentricus, Renilla kollikeri, Tivela stultorum, Stylatula elongata, Diopatra ornata and Astropecten spp.) represent the bulk of the community's biomass but, because of their longevity and relative freedom from predation, show low turnover of this biomass. The long-term presence of the ecological dominant organisms, particularly the sand dollar, is a major factor that affects the character of many of the other populations within this sand community. The position of this bed appears to have a profound influence on the distribution of other members of the community particularly through competition for space. Deeper water creeping organisms forage shoreward until constrained by the physical effect of water turbulence and resulting sand scour or, alternatively, are competitively blocked from these regions by the massive numbers of herd-like sand dollars.

We have provided evidence that this California subtidal sand habitat contains a highly structured zonally organized community dominated by specialized organisms that dynamically modulate their populations through complex interactions with the physical environment and with each other.

Acknowledgements. We thank the other divers who contributed substantial time, thought and energy in helping us collect the data. These include D. Crandall, D. Costa, R. Vance and especially M. Tarttelin. For numerous helpful discussions and comments we gratefully acknowledge $T$ Ronan, E. Hobson, R. Vance, R. Fay, and J. Vallee. We owe a special thanks to the Los Angeles County Lifeguards for their occasional assistance, watchfulness and concern for our safety, and the generous use of their thorough physical data. We also thank R. Highsmith, R. Emlet, M. Shulman, P. Dayton, C. Peterson, and A. Kohn for their critical reviews and comments that substantially improved the product. This research was supported in part by USPHS Grant NS 09546 and University Research Grants to J. G. M.

\section{LITERATURE CITED}

Alldredge, A. L., King, J. M. (1977). Distribution, abundance, and substrate preference of demersal reef zooplankton at Lizard Island Lagoon, Great Barrier Reef. Mar. Biol. 41: $317-333$

Alldredge, A. L., King, J. M. (1980). Effect of moonlight on the vertical migration patterns of demersal zooplankton. J exp. mar. Biol. Ecol. 44: 133-156

Bascom, W. N. (1964). Waves and beaches: the dynamics of the ocean surface. Doubleday and Co., Inc., Garden City New York

Bell, B. M., Frey, R. W. (1969). Observations on ecology and the feeding and burrowing mechanisms of Mellita quinquiesperforata (Leske). J. Paleont. 43: 553-560

Birkeland, C., Chia, F. S. (1971). Recruitment risk, growth, age and predation in two populations of Dendraster excentricus (Eschscholtz). J. exp. mar. Biol. Ecol. 6: $265-278$

Cameron, R. A., Rumrill, S. S. (1982). Larval abundance and recruitment of the sand dollar Dendraster excentricus in Monterey Bay, California, USA. Mar. Biol. 71: 197-202

Chia, F. S. (1969). Some observations on the locomotion and feeding of the sand dollar, Dendraster excentricus (Eschscholtz). J. exp. mar. Biol. Ecol. 3: 162-170

Coe, W. R., Fitch, J. E. (1950). Population studies, local growth rates and reproduction of the Pismo clam (Tivela stultorum). J. Mar. Res. 9 (3): 188-210

Collette, B. B., Talbot, F. H. (1972). Activity patterns of coral reef fishes with emphasis on nocturnal-diurnal changeover. Bull. Nat. Hist. Mus. Los Angeles County 14: 98-124

Davis, N. (1978). Studies of the southern California nearshore sand bottom community. Doctoral dissertation. Univ. of California, San Diego

Davis, N., VanBlaricom, G. R. (1978). Spatial and temporal heterogeneity in a sand bottom epifaunal community of invertebrates in shallow water, Limnol. Oceanog. 23: $417-427$

Dayton, P. K., Robilliard, G. A., Paine, R. T. (1970). Benthic faunal zonation as a result of anchor ice at McMurdo Sound, Antarctica. Antarc. Ecol. 1: 244-258 (Holdgate, M.: ed.) Academic Press, New York

Dexter, D. M. (1977). A natural history of the sand dollar Encope stokesi L. Agassiz in Panama. Bull. mar. Sci. 27 : 554-557

Dexter, D. M. (1978). The infauna of a subtidal, sand-bottom community at Imperial Beach, California. Calif. Fish Game 64 (4): 268-279

Dingle, H. (1972). Migration strategies of insects. Science 175: $1327-1335$

Ebert, T. A., Dexter, D. M. (1975). A natural history study of Encope grandis and Melitta grantii, two sand dollars in the northern Gulf of California, Mexico. Mar. Biol. 32: $397-406$

Ebeling, A. W., Bray, R. N. (1976). Day versus night activity of 
reef fishes in a kelp forest off Santa Barbara, California Fish. Bull. U. S. 74: 703-717

Emerson, R. R. (1976). The biology of a population of Diopatra ornata at Santa Catalina Island, California. Doctoral dissertation. Univ, of Southern California, Los Angeles

Emery, A. R. (1973). Preliminary comparisons of day and night habits of freshwater fish in Ontario Lakes. J. Fish. Res. Bd Can. 30: 761-774

Emery, K. O. (1960). The sea off southern California. A modern habitat of petroleum. John Wiley and Sons, New York

Fager, E. W. (1968). A sand-bottom epifaunal community of invertebrates in shallow water Limnol. Oceanog. 13: $448-464$

Goldberg, W. M. (1973). The ecology of the coral-octocoral communities of the southeast Florida coast: geomorpholagy, species composition and zonation. Bull. mar. Sci. 23: $465-488$

Gray, J. S. (1974). Animal-sediment relationships. Oceanogr. mar. Biol. A. Rev. 12: 223-261

Gwinner, E. G. (1975). Circadian and circannual rhythms in birds. In: Farner, D. S., King, J. R. (ed.) Avian biology, Vol. 5. Academic Press, New York, p. 221-285

Hedgpeth, J. W. (1957). Sandy beaches. In: Hedgpeth, J. W. (ed.) Treatise on marine ecology and paleoecology, Vol. 1, Ecology. Geol. Soc. Am. Memoir No. 67, p. 587-608

Highsmith, R. C. (1982). Induced settlement and metamorphosis of sand dollar (Dendraster excentricus) larvae in predator-free sites: adult sand dollar beds. Ecology 63: 329-337

Hobson, E. S. (1965). Diurnal-nocturnal activity of some inshore fishes in the Gulf of California. Copeia 1965: 291-302

Hobson, E. S. (1972). Activity of Hawaiian reef fishes during the evening and morning transition between daylight and darkness. Fish. Bull. U. S. 70: 715-740

Hobson, E. S., Chess, J. R. (1976). Trophic interactions among fishes and zooplankters near shore at Santa Catalina Island, California. Fish. Bull. U. S. 74: 567-598

Hobson, E. S., McFarland, W. N., Chess, J. R. (1981). Crepuscular and nocturnal activities of Californian nearshore fishes with consideration of their scotopic visual pigments and the photic environment. Fish. Bull. U. S. 79: 715-740

Hurley, A. C. (1973). Larval settling behaviour of the acorn barnacle (Balanus pacificus Pilsbry) and its relation to distribution. J. Anim. Ecol. 42: 599-609

Kastendiek, J. E. (1975). The role of behavior and interspecific interactions in determining the distribution and abundance of Renilla kollikeri Pfeffer, a member of a subtidal sand bottom community. Doctoral dissertation. Univ. of California, Los Angeles

Kastendiek, J. E. (1976). Behavior of the sea pansy Renilla hollikeri Pfeffer (Coelenteratd: Pennatulacea) and its influence on the distribution and biological interactions of the species. Biol. Bull. mar biol. Lab., Woods Hole 151: 518-537

Kastendiek, J. E. (1982). Factors determining the distribution of the sea pansy, Renilla kollikeri, in a subtidal sandbottom habitat. Oecologia (Berl.) 52: 340-347

Kinzie, R. A. (1973). The zonation of West Indian gorgonians Bull. mar. Sci. 23: 93-155

MacGinitie, G. E., MacGinitie, N. (1949). Natural history of marine animals. McGraw-Hill Book Co., Inc., New York

Merrill, R. J., Hobson, E. S. (1970). Field observations of Dendraster excentricus, a sand dollar of western North America. Am. Midl. Nat. 83: 585-624

Meyer, R. E. (1972). Waves on beaches and resulting sediment transport. Academic Press, New York
Niesen, T M. (1977). Reproductive cycles in two populations of the Pacific sand dollar Dendraster excentricus. Mar Biol. 42: 365-374

Oliver, J. S., Slattery, P. N., Hulberg, L. W., Nybakken, J. W (1980). Relationships between wave disturbance and zonation of benthic invertebrate communities along a subtidal high-energy beach in Monterey Bay, California. Fish. Bull. U. S. 78: $437-454$

O'Neill, P. L. (1978). Hydrodynamic analysis of feeding in sand dollars. Oecologia (Berl.) 34: 157-174

Parks, N. B. (1973). Distribution and abundance of the sand dollar Dendraster excentricus off the coast of Oregon and Washington. Fish. Bull. U. S. 71: 1105-1108

Pequegnat, $W$ E. (1966). The epifauna of a California siltstone reef. Ecology 45: 272-283

Pequegnat, W. E. (1968). Distribution of epifaunal biomass on a sublittoral rock reef. Pacif. Sci. 22: 37-40

Peterson, C. H. (1977). Competitive organization of the softbottom macrobenthic communities of southern California lagoons. Mar. Biol. 43: 343-359

Peterson, C. H., Andre, S. V. (1980). An experimental analysis of interspecific competition among marine filter feeders in a soft-sediment environment. Ecology 61: 129-139

Porter, J. W., Porter, K. G. (1977). Quantitative sampling of demersal plankton migrating from different coral reef substrates. Limnol. Oceanog. 22: 553-556

Rhoads, D. C. (1974). Organism-sediment relations on the muddy sea floor. Oceanogr. mar. Biol. A. Rev. 12: 263-300

Ricketts, E. F., Calvin, J., Hedgpeth, J. (1968). Between Pacific tides. Stanford Univ. Press, Stanford

Smith, A. L. (1981). Comparison of macrofaunal invertebrates in sand dollar (Dendraster excentricus) beds and in adjacent areas free of sand dollars. Mar Biol. 65: 191-198

Sokolova, M. N., Kusnetzov, A. P. (1960). On the feeding character and the role played by trophic factors in the distribution of the sea urchin Echinarachnius parma. Zool. Zh. 39: 1253-1256

Stanley, D. J., James, N. P. (1971). Distribution of Echinarachnius parma (Lamarck) and associated fauna on Sable Island Bank, southeast Canada. Smithson. Contr Earth Sci. 6: 1-24

Stephens, G. C., Volk, M. J., Wright, S. H., Backlund, P. S (1978). Transepidermal accumulation of naturally occurring amino acids in the sand dollar, Dendraster excentricus. Biol. Bull mar. biol. Lab., Woods Hole 154: 335-347

Stephenson, T. A., Stephenson, A. (1972). Life between tidemarks on rocky shores. W H. Freeman and Co., San Francisco

Telford, M. (1981). A hydrodynamic interpretation of sand dollar morphology. Bull. mar. Sci. 31: 605-622

Timko, P. L. (1975). High density aggregation in Dendraster excentricus (Eschscholtz): analysis of strategies and benefits concerning growth, age structure, feeding, hydrodynamics, and reproduction. Doctoral dissertation. Univ of California, Los Angeles

Timko, P. L. (1976). Sand dollars as suspension feeders: a new description of feeding in Dendraster excentricus. Biol. Bull. mar biol. Lab., Woods Hole 151: 247-259

Timko, P. L. (1979). Larviphagy and oophagy in benthic invertebrates: a demonstration for Dendraster excentricus (Echinoidea). In: Stancyk, S. E. (ed.) Reproductive ecology of marine invertebrates. Univ. South Carolina Press, Columbia, p. 91-98

VanBlaricom, G. R. (1982). Experimental analyses of structural regulation in a marine sand community exposed to oceanic swells. Ecol. Monogr 52: 283-305

Virstein, R. W. (1977). The importance of predation by crabs 
and fishes on benthic infauna in Chesapeake Bay. Ecology 58: $1199-1217$

Virstein, R. W. (1979). Predation on estuarine infauna: response patterns of component species. Estuaries 2: 69-86

Wiltse, W. I. (1980). Effects of Polinices duplicatus (Gastropoda: Naticidae) on infaunal community structure at Barnstable Harbor, Massachusetts, USA. Mar. Biol. 56: $301-310$
Woodin, S. A. (1974). Polychaete abundance patterns in a marine soft-sediment environment: importance of biological interactions. Ecol. Monogr. 44: 171-187

Woodin, S. A. (1978). Refuges, disturbance, and community structure: a marine soft-bottom example. Ecology 59: $274-284$

Woodin, S. A. (1981). Disturbance and community structure in a shallow water sand flat. Ecology 62: 1052-1066

This paper was presented by Professor N. D. Holland; it was accepted for printing on August 20, 1985 